\title{
How can we cure a heart "in flame"? A translational view on inflammation in heart failure
}

\author{
Ulrich Hofmann · Stefan Frantz
}

Received: 15 January 2013/Revised: 3 April 2013/Accepted: 8 April 2013/Published online: 6 June 2013

(C) The Author(s) 2013. This article is published with open access at Springerlink.com

\begin{abstract}
The prevalence of chronic heart failure is still increasing making it a major health issue in the 21 st century. Tremendous evidence has emerged over the past decades that heart failure is associated with a wide array of mechanisms subsumed under the term "inflammation". Based on the great success of immuno-suppressive treatments in auto-immunity and transplantation, clinical trials were launched targeting inflammatory mediators in patients with chronic heart failure. However, they widely lacked positive outcomes. The failure of the initial study program directed against tumor necrosis factor- $\alpha$ led to the search for alternative therapeutic targets involving a broader spectrum of mechanisms besides cytokines. We here provide an overview of the current knowledge on immune activation in chronic heart failure of different etiologies, summarize clinical studies in the field, address unresolved key questions, and highlight some promising novel therapeutic targets for clinical trials from a translational basic science and clinical perspective.
\end{abstract}

Keywords Cytokines - Heart failure ·

Immuno-modulation

This article is part of the Topical Collection Novel Perspectives on Heart Failure.

U. Hofmann · S. Frantz ( $₫)$

Department of Internal Medicine I, University Hospital

Würzburg, Oberdürrbacher Straße 6, 97080 Würzburg, Germany

e-mail: frantz_s@klinik.uni-wuerzburg.de

U. Hofmann

e-mail: Hofmann_u2@klinik.uni-wuerzburg.de

U. Hofmann · S. Frantz

Comprehensive Heart Failure Center, University of Würzburg,

Straubmühlweg 2a, Würzburg, Germany

\section{Introduction}

Congestive heart failure (CHF) is a leading cause for both hospitalization and death in the western world. Its prevalence is rather increasing with the broad implementation of standardized evidence-based treatment algorithms for heart failure. The heart failure syndrome is characterized by impaired systolic and/or diastolic function and various clinical signs such as fatigue, dyspnea, fluid retention, and cachexia. Besides symptomatic treatment to relieve these symptoms several classes of drugs improve the prognosis of patients with chronic heart failure. These agents target the so-called neurohumoral activation process that comes along with the evolution of the heart failure syndrome irrespective of the underlying pathophysiology. Inhibition of the activity of the renin-angiotensin-aldosterone system and $\beta$-adrenergic signaling are well-established treatment principles which are incorporated in current guidelines [100]. However, morbidity and mortality remain substantial in chronic heart failure patients despite optimal medical and device therapy, the indication for which has recently been broadened [100].

An inflammatory activation in CHF patients has long been recognized. Indeed, immune mechanisms modulate interstitial fibrosis, cardiomyocyte apoptosis, and hypertrophy, all of which are central processes leading to maladaptive remodeling in response to a variety of stimuli (Fig. 1). Especially for heart failure evolving from large myocardial infarction there is substantial evidence for a causal contribution of immunity early in the course of the disease.

First, systemic cytokines came into focus, which have been monitored in several clinical trials [33, 112]. The broadest amount of data was gathered for tumor necrosis factor- $\alpha($ TNF- $\alpha)$ [78] which was demonstrated to correlate 
Fig. 1 Schematic overview depicting activation mechanisms of both innate and adaptive immunity and their central effector mechanism reviewed here

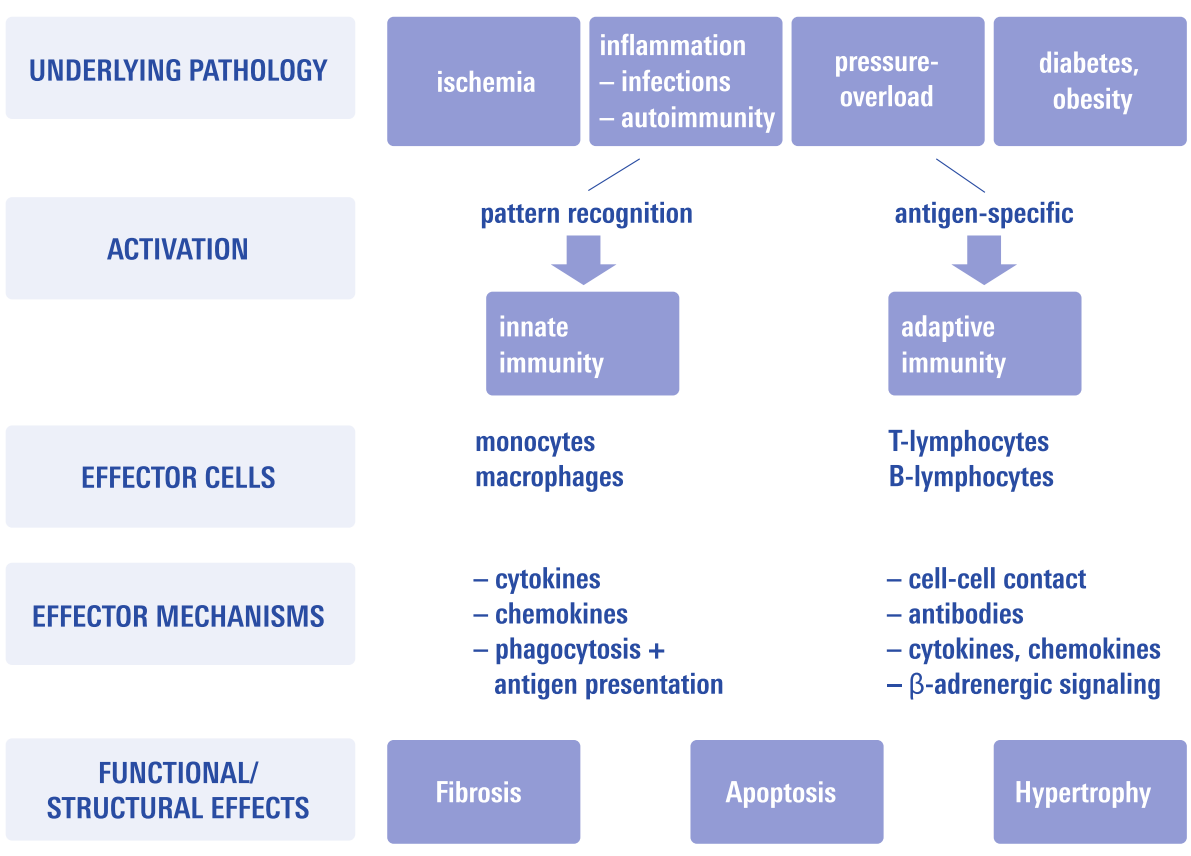

well with diverse clinical and laboratory parameters, such as exercise capacity and neurohormonal activation in $\mathrm{CHF}$ patients [26]. These observations lead to the conduction of clinical trials testing anti-TNF- $\alpha$ drugs in chronic heart failure patients $[25,96]$. Their discouraging results have raised important questions on the significance of the inflammatory activation in chronic heart failure. It is still unresolved whether these trials treated the right patients with the right drugs [4] or whether the whole concept of anti-cytokine therapy mainly based on small animal studies does not work in a heterogeneous population of patients with chronic heart failure of diverse etiology.

Meanwhile, basic science and translational clinical research gathered a lot of mechanistic information on new players in the field of inflammation which constitute very promising future targets for therapy. Therefore, a recent scientific statement from the European Society of Cardiology defined key questions and requirements for future studies in the enormously expanding field [61].

The current review will provide the reader with an elected overview of experimental and clinical evidence for immune activation in chronic heart failure, summarize key clinical trials addressing the immune system, and provide an outlook for several new promising clinical targets.

\section{Evidence for immune activation in heart failure of different etiology}

Different etiologies like coronary artery disease, hypertension, infection, etc., lead to heart failure. Therefore, one of the key questions in the field is whether activation of immunity in humans and animal models of heart failure is independent of the etiology or if there are disease specific mechanisms. As it turns out, both are the case.

Different heart failure models indicate a role of innate immunity independent of heart failure etiology. Innate immunity is activated in the myocardium early by recognition of rather unspecific stimuli, summarized as dangerassociated molecular patterns [10]. This form of sterile inflammation is prototypically initiated by engagement of innate pattern recognition receptors, like toll-like receptors [68].

It is likely that inflammation is also initiated in human myocardium by innate recognition of pathogen-associated molecular pattern even well before the heart failure becomes symptomatic/diagnosed. However, clinical data to corroborate findings made in animal studies are widely limited to the demonstration of increased circulating levels of soluble mediators, mainly cytokines [78], in a variety of patient cohorts with heart failure.

For heart failure with reduced ejection fraction due to different clinical etiologies there is good evidence from both experimental and clinical studies that pro-inflammatory cytokines are locally expressed in myocardium. For example, TNF- $\alpha$ has been mechanistically related to more or less all etiologies of systolic heart failure. Besides its direct effect on myocardial contractile function $[35,155]$, TNF- $\alpha$ contributes to progressive myocardial remodeling. This is underscored by the demonstration that chronic systemic administration of TNF- $\alpha$ in concentrations found in CHF patients [14] or its transgenic myocardial expression produces a DCM-like phenotype [79]. 
Nevertheless, there are also distinct differences in the activation of the immune system in different heart failure etiologies:

\section{Ischemic heart failure}

Heart failure due to large myocardial infarction is the most prevalent cause of systolic heart failure, so the majority of small animal studies for heart failure were conducted in the permanent myocardial infarction model. Besides early infiltration of leukocytes and local expression of cytokines and chemokines, there is ongoing inflammation that extends to the remote myocardium and is a part of the underlying pathophysiology of left ventricular remodeling. A detailed review of all the processes involved in myocardial remodeling is beyond the scope of the present article and was summarized recently [42]. Inflammation mainly involves innate immunity mechanisms including toll-like receptor activation $[44,68]$ and $\mathrm{NF \kappa B}$ intracellular signaling both in local cells (cardiomyocytes, fibroblasts) and in infiltrating leukocytes [45]. Clinical evidence for the activation of adaptive immunity is comparatively sparse. However, the increased prevalence of auto-antibodies against structural components of [30] and cell surface receptors on cardiomyocytes [129] indicates that ischemic injury can induce an adaptive auto-immune response against myocardial tissue.

Most animal studies are performed in relatively acute settings with follow-up of no longer than 8 weeks. Especially experiments with genetically altered mice often do not really allow distinguishing the effect on initial myocardial injury and wound healing, when the most pronounced inflammatory activation takes place, from chronic remodeling of the myocardium. Therefore, therapeutic approaches based on such animal experiments rather reflect the clinical situation weeks to months after a myocardial infarction when mechanisms, such as infarct expansion are still operative and do not easily allow transfer of the findings to the situation of chronic, non-ischemic, systolic heart failure.

In contrast to the broad evidence from small animal studies, due to the limited availability of myocardial specimens clinical evidence for immune activation in chronic ischemic heart failure mainly comes from analysis of cytokines and cytokine receptors in peripheral blood [8] which first led to the design of anti-cytokine trials, as summarized below.

\section{Inflammatory heart disease}

The threshold of $>14$ leukocytes $/ \mathrm{mm}^{2}$ is widely accepted for the definition of myocardial inflammation [113]. Endomyocardial biopsy allows further differentiation between virus-positive and virus-negative inflammatory cardiomyopathy. Human herpesvirus 6 and Parvo B19 virus are the most prevalent viruses found in myocardial biopsy specimens from patients with suspected myocarditis [94]. Besides direct virus mediated cardiac injury, the ensuing immune response, mainly studied in coxsackievirus B3 small animal models of myocarditis, significantly contributes to myocardial injury and to the development of chronic heart failure [28]. Transition into sustained myocardial inflammation despite halted virus replication by induction of auto-immunity further propagates local inflammation and eventually leads to progressive myocardial fibrosis with transition to the clinical entity DCM [27]. Animal models of myocarditis demonstrated that the genetic background plays an important role for modulating the adaptive immune response, involving the cooperation of innate immune cells and lymphocytes for induction of persistent myocardial inflammation even after virus control as a transition to autoimmunity [36]. However, we still do not really understand why some patients control or even eliminate viral infection of the heart, whereas others develop progressive deterioration leading to DCM. This also relates to the unknown pathophysiological significance of a high prevalence of viral genome without evidence of local inflammation, even in healthy hearts [80, 91]. Referring to this, Kindermann et al. [76] reported recently that the detection of immunohistological evidence of inflammatory infiltrates and HLA class II expression in the myocardium rather than detection of virus genome is of prognostic relevance in patients with suspected myocarditis.

It is further unclear whether, in analogy to mouse models of auto-immune myocarditis induced by vaccination against myocardial proteins, auto-immune myocarditis develops in patients without previous infection of the myocardium. Data from the TIMIC trial [48] demonstrating that a differentiation into virus-positive and -negative inflammatory cardiomyopathy identifies patients which could benefit from immunosuppression by steroids + azathioprine indicate that autoimmune cardiomyopathy might indeed constitute a pathophysiologically distinct clinical entity. This does not exclude that myocardial auto-immunity in man might always be initiated by the adjuvant effect of concomitant myocardial or systemic infection which might break tolerance to myocardial structural components. Thus, at the moment, a careful analysis of the presence of virus genome in the myocardium in an experienced laboratory seems to be mandatory, at least for further clinical trials in the field.

Heart failure with preserved ejection fraction, myocardial hypertrophy

Chronic pressure overload also leads to the expression of chemokines, cytokines, and infiltration of monocytes in the 
myocardium. Most evidence comes from animal models of transverse aortic constriction. There is a welldescribed pathophysiological link between inflammation and fibrosis [13, 83], whereas the link to hypertrophy is less well established. Especially macrophages play a central role for development of interstitial fibrosis in response to different stimuli. Alternatively activated macrophages induce fibrosis by expression of proteins like arginase, coagulation factor XIII, and TGF- $\beta$ [151]. Experimentally, T-cells contribute to the pathophysiology of myocardial fibrosis. T-cell derived IL-18 can induce osteopontin expression and fibrosis in myocardium [157]. In a mouse model of hypertension, lymphocyte deficient SCID mice were protected against myocardial collagen accumulation. There was less fibrillar collagen cross-linking and reduced activity of the cross-linking enzyme lysyl-oxidase-like-3 compared to wild type C57B6 mice and even higher collagen content in Th2 biased BALB/c mice [156] indicating that $\mathrm{CD}^{+}{ }^{+} \mathrm{T}$-cells, especially modulate collagen deposition in myocardium.

An expression of pro-inflammatory cytokines was also described in myocardium from patients with aortic stenosis [146]. Here, the pathomechanism underlying the transition from adaptive hypertrophy to irreversible remodeling and decompensation is incompletely understood and might also implicate fundamental changes in the inflammatory response.

Inflammation in heart failure with preserved ejection fraction without overt hypertrophy has been less well characterized. In patients with coronary artery disease and diabetes, a small study found an association between proinflammatory serum cytokines and echocardiographic evidence of diastolic dysfunction [34].

In sum, clinical evidence for the implication of inflammation in the development of myocardial hypertrophy and diastolic dysfunction is sparse, although experimental studies suggest a role especially for lymphocytes and macrophages.

\section{Diabetes and obesity}

More and more evidence is accumulating that obesity is associated with a systemic inflammatory response that is characterized by endothelial cell dysfunction, oxidative stress, and the activation of leukocytes [118]. The inflammatory response mediated by hormones from adipose tissue, like adiponectin, might contribute to cardiac remodeling in obesity [109]. Data on the functional status of the myocardium in advanced obesity are ambiguous reporting either normal or impaired diastolic, some even impaired systolic function in different cohorts [2]. It is thus still not quite clear, whether obesity leads to heart failure independently from coronary heart disease.

The amount of epicardial fat was often correlated with the severity of hypertrophy and cardiac dysfunction as evidenced mainly by non-invasive imaging with its inherent limitations in obese humans. Especially the adipocytokine adiponectin, which is decreased in patients with obesity-linked diseases, prevents left ventricular hypertrophy. Studies in adiponectin deficient mice revealed increased afterload-induced hypertrophy due to impaired activation of the activated protein kinase AMP [117]. However, the results from a variety of animal models of diabetes and obesity are ambiguous in terms of cardiac function and the contribution of metabolic changes concerning substrate utilization and hyperglycemia on the one hand, and adipose tissue-derived inflammation on the other, for the myocardial phenotype observed $[2,37,158]$.

\section{Therapeutic approaches in clinical trials}

\section{Cytokine targeting}

The best studied pro-inflammatory cytokine in the scenario of heart failure is TNF- $\alpha$ [78, 102]. Clinical studies have shown elevated serum levels of TNF- $\alpha$ in patients with decompensated CHF, especially in those with cachexia [107]. There is further good evidence from experimental studies that TNF- $\alpha$ has an immediate negative effect on contractile function $[35,155]$ and the economy of contraction [67]. TNF- $\alpha$ elicits immediate negative inotropic effects mainly via binding to TNF-receptor 1 (TNFR1). Its activation induces the formation of sphingosine which reduces calcium release from the sarcoplasmic reticulum $[47,138]$ and decreases $\beta$-adrenergic receptor coupling leading to diminished sarcoplasmic reticulum calcium pump activity [82]. Furthermore, TNF- $\alpha$ increases ROS formation by uncoupling mitochondrial respiration [18] which in turn promotes myocardial dysfunction by oxidation of contractile filaments [24]. The clinical relevance of these findings has not yet been tested by a clinical trial testing neutralization of TNF- $\alpha$ in patients with acute/ decompensated heart failure.

Besides its immediate effects on the contractile performance of the myocardium, there is also good experimental evidence for a causal pathophysiological role of TNF- $\alpha$ for the progression of myocardial remodeling leading to chronic heart failure. Relevant mechanism demonstrated in experimental studies are induction of cardiomyocyte hypertrophy [154], induction of cardiomyocyte apoptosis [160], and progressive left ventricular dilation by inducing matrix-protease activity [89]. 
Based on these extensive animal data indicating a causal link between TNF- $\alpha$ and cardiac dysfunction in both the acute and chronic setting, clinical trials were launched which tested compounds initially developed for binding of TNF- $\alpha$ in rheumatic diseases. The compound etanercept consists of two human TNF- $\alpha$ receptor fragments linked to the Fc portion of immunoglobulin G. In a phase I study, etanercept single administration was well tolerated and improved ejection fraction in chronic heart failure patients [32]. Etanercept treatment over 3 months then showed improvement in clinical parameters and ejection fraction [15]. These pilot trials confirmed the expectations based on animal studies and led to the initiation of large multicenter trials (RECOVER, RENAISSANCE, RENEWAL) testing the long-term effect of etanercept in chronic heart failure patients with NYHA III-IV functional status and EF $\leq 30 \%$. In fact, on the basis of pre-specified stopping rules, the trials were terminated prematurely. Etanercept had no effect on clinical status in RENAISSANCE or RECOVER and had no effect on the death or chronic heart failure hospitalization endpoint in RENEWAL, which analyzed the outcome from a high dose subgroup of patients of both trials [96].

Infliximab is a chimeric antibody binding soluble and membrane-bound TNF- $\alpha$ and prevents it from binding to its receptors. In a smaller phase II trial (ATTACH), NYHA III-IV patients treated with lower doses of infliximab demonstrated an increase in ejection fraction, but there was an increased risk of hospitalization and death in a high dose group [25].

Besides dosing and timing issues, two main points have been worked out as possible explanations for the disillusioning results [4]. First, cardiomyocytes can express TNF$\alpha$ on the cell membrane [35, 142, 143]. Binding of infliximab is expected to induce apoptosis in cells expressing membrane-bound TNF- $\alpha$. Second, etanercept and infliximab were suspected to prolong the half-life/bioavailability of TNF- $\alpha$. Accordingly, patients treated with infliximab revealed increased concentrations of TNF- $\alpha$ [25]. This might explain why single doses of etanercept in the phase I study appeared to be beneficial, whereas long-term treatment is obviously detrimental.

The disappointing results of the anti-TNF- $\alpha$ studies in CHF patients dampened the enthusiasm in the field and supported a common belief that the redundancy of the immune system precludes success of specific cytokinetargeting strategies. Thus, although other pro-inflammatory cytokines were demonstrated to be involved in cardiac injury and significantly correlated with clinical status and prognosis of patients with chronic heart failure [56], especially IL-6 has to be mentioned here [75], there was no further prospective randomized clinical trial targeting cytokines in chronic heart failure patients. Several drugs approved for unrelated indications possess anti-inflammatory, anti-oxidant, or immuno-modulatory properties and were tested in patients with acute or chronic heart failure thereafter.

\section{Glucocorticoids}

One of the first randomized trials on immuno-modulation was conducted years before the event of the anti-TNF- $\alpha$ trials. Glucosteroids were tested in a number of small studies before the advent of current reperfusion therapy. A number of rather small studies produced controversial results when patients were treated in the setting of an acute myocardial infarction to limit infarct size and improve wound healing [88]. Later on, glucosteroids were tested in CHF patients. In idiopathic DCM patients, prednisone treatment induced a very modest, transient effect on ejection fraction in a subgroup with histological evidence of inflammation [108]. Accordingly, combined treatment with glucosteroids and azathioprine showed a beneficial on left ventricular function in DCM patients selected by myocardial HLA up-regulation in myocardial biopsy specimens [150]. The utility of immunosuppression by steroids was proven later in the randomized, placebo-controlled TIMIC trial [48]. Patients with chronic biopsy proven virus-negative inflammatory cardiomyopathy benefited from prednisone/azathioprine treatment in terms of a significant improvement of left ventricular ejection fraction compared with both baseline and the control group. Yet, no long-term follow-up data with further clinical endpoints are available from this trial.

\section{Thalidomide}

Thalidomide was initially believed to act as an anti-TNF- $\alpha$ agent. In a small pilot uncontrolled trial, thalidomide rather increased plasma levels of TNF- $\alpha$ in patients with chronic heart failure, but improved left ventricular function [54]. Thalidomide treatment for 12 weeks induced reverse remodeling of the left ventricle in a subsequent small randomized trial. Improvement in LVEF was accompanied by a decrease in matrix metalloproteinase- 2 suggesting a matrix-stabilizing rather than an anti-inflammatory effect [55].

Statins

Statins are well known for their "pleiotropic" effects besides cholesterol lowering. Immuno-modulatory and anti-inflammatory effects have been described which in part, inter alia, relate to attenuation of T-cell activation by repression of MHC-II expression [85]. Rosuvastatin was, therefore, studied in two clinical trials in patients with 
chronic heart failure. The CORONA trial tested the efficacy of rosuvastatin in a mixed CHF population [77]. Rosuvastatin did not reduce the primary outcome, although the drug did reduce the number of cardiovascular hospitalizations. In the unrelated GISSI-HF trial, rosuvastatin was also tested in patients with chronic heart failure, irrespective of underlying cause and left ventricular ejection fraction. Here, the drug did not affect pre-specified clinical outcomes [134]. Therefore, based on a fairly large cohort of chronic heart failure patients studied in clinical trials, rosuvastatin treatment could not prove a benefit as adjunct to current heart failure medication.

\section{Pentoxifylline}

Pentoxifylline is a phosphodiesterase inhibitor which is approved for the treatment of peripheral vascular disease. The initial rationale for using pentoxifylline was due to its ability to inhibit TNF- $\alpha$ transcription. Yet, not all studies could link improvements in clinical outcome to a concordant effect on TNF- $\alpha$ modulation [116].

In several clinical trials, pentoxifylline therapy was reported to reduce circulating levels of C-reactive protein, FASL, and TNF- $\alpha$ in heart failure patients. In those small heart failure trials, pentoxifylline also improved ejection fraction and functional outcome [119, 120, 122, 124]. However, a clinical trial from an unrelated group demonstrated that treatment with pentoxifylline had no significant effect on left ventricular function, inflammatory cytokines, and symptoms in patients with cardiomyopathy of various etiologies [9]. Pentoxifylline was also tested in women with peripartum cardiomyopathy and produced promising effects on a combined outcome endpoint [121]. Whereas most studies included patients with mild-to-moderate heart failure, another trial tested pentoxyphilline in a small NYHA IV patient cohort. This prospective, placebo-controlled study revealed an increase in ejection fraction after 1 month [123].

\section{Anti-oxidants}

Oxidative stress is believed to play a causative role in the evolution of the heart failure syndrome mainly on the basis of experimental studies. On the cellular level, reactive oxygen species can activate multiple signaling pathways, including MAP kinases and nuclear factor- $\kappa \mathrm{B}$ [69]. This induces expression of pro-inflammatory cytokines like TNF- $\alpha$, which again promotes ROS formation and proapoptotic signaling as a potential positive feedback mechanism after myocardial infarction or chronic pressure overload [153]. Myofibrillar protein oxidation was shown in an animal model of coronary microembolisation [24] and a pacing-induced heart failure model [60]. Of note, oxidative modification of myofibrillar proteins was subsequently also found in human failing hearts [23, 59]. A potential role for generation of oxidative stress was further underscored by the clinical observation that there is a significant positive correlation between the clinical class of heart failure and several biochemical parameters of oxidative stress in patients with chronic heart failure [73]. Therefore, a randomized trial was conducted to study whether oxypurinol, a xanthine oxidase inhibitor expected to reduce the production of reactive oxidant species, produces clinical benefits in patients with NYHA class III/IV heart failure. Oxypurinol did not produce clinical improvements [57]. The effect of allopurinol on diastolic function in chronic heart failure patients was further studied in a recent, yet unpublished, trial (NCT00477789).

Another small double-blinded controlled randomized trial aimed to determine whether vitamin E supplementation of patients with advanced heart failure (NYHA III/IV) would modify levels of oxidative stress and improve functional status and prognosis. However, supplementation with vitamin $\mathrm{E}$ did not result in any significant improvements [74].

Despite the theoretical potential of adding anti-oxidants to standard heart failure medication, which might have been underestimated on the basis of these rather small trials, it has to be mentioned that standard heart failure medication already includes drugs with anti-oxidant properties, especially ACE inhibitors and angiotensin receptor blockers [140].

On the other hand, the addition of a fixed dose of isosorbide dinitrate plus hydralazine to standard therapy for heart failure improved survival among black patients with advanced heart failure in the AHeFT trial [135, 136]. This drug combination includes a nitric oxide donor (isosorbide dinitrate) and an antioxidant (hydralazine) to protect NO from degradation. Anti-oxidant mechanisms improving NO bioavailability and, thus, endothelial dysfunction were discussed to contribute to the observed effect [40]. The results of AHeFT indicate that there might be considerable variation in the significance of the role of oxidative stress and endothelial function according to ethnical background.

Immune modulation by modified autologous blood

Autologous blood exposed ex vivo to heat and oxidative stress induces anti-inflammatory effects in animal models [106]. The precise mechanism has not been studied, especially in humans. One might speculate that apoptotic cells contained in the autologous blood could have an important contribution to the immuno-modulatory effect [147]. Based on these experimental results, a small randomized phase II study was conducted in NYHA III-IV heart failure patients. This study demonstrated a significantly reduced 
risk of death and hospitalization [144]. The subsequent placebo-controlled ACCLAIM trial did not find a significant reduction of hospitalization or mortality in over 2,400 NYHA III-IV patients studied during 12 months [141].

\section{PUFA}

Considerable epidemiological data found an association of omega-3 polyunsaturated fatty acid ( $\omega-3$ PUFA) intake, mainly from fish oils, and cardiovascular endpoints (reviewed in [87]). Reduction of coronary events seems to contribute most to the total effect. A recent prospective study of nearly 60,000 Japanese people with a high intake of fish, followed-up for over 12 years, revealed an inverse association between fish, PUFA consumption, and mortality, especially for heart failure [152]. PUFAs have multiple immuno-modulating properties including effects on arachidonic acid metabolism and peroxisome proliferator-activated receptors (PPARs) [103].

Dietary PUFA supplementation was studied by the Gruppo Italiano per lo Studio della Sopravvivenza nell'Infarto Miocardico-Heart Failure (GISSI-HF) study, a large-scale clinical trial in a chronic heart failure cohort. This trial showed a moderate, albeit significant benefit of $\omega-3$ PUFA in addition to standard heart failure medication [133]. The mechanism behind it is not yet clear. The beneficial effect on mortality seemed not to rely on prevention of sudden cardiac death as in the GISSI prevention trial [1]. Recently, in a small double-blind, randomized, controlled trial two doses of PUFA were tested in patients with advanced, non-ischemic heart failure. Treatment with PUFA for 3 months led to a dose-dependent increase of LVEF [104].

Based on these trials the clinical relevance of PUFAs in chronic heart failure patients is still not clear. Thus, PUFA supplementation received a class IIb, level of evidence B recommendation in the most current European heart failure guideline [99].

Immuno-adsorption, antibody neutralization

There is a considerable proportion of patients with chronic heart failure, especially DCM, which have auto-antibodies [21]. The high prevalence of viral genome in idiopathic forms [92] and the presence of myocardial auto-antibodies in asymptomatic relatives to familial DCM patients [20, 22] puts the heterogeneous clinical entity of DCM in an exceptional immunological position. The pathophysiological relevance of auto-antibodies in humans with heart failure has not yet been finally defined, whereas there is experimental evidence from rodent models that auto-antibodies especially against the $\beta 1$-adrenergic receptor can induce a dilated cardiomyopathy phenotype [72]. The functional effect of $\beta 1$-adrenergic receptors, which are of note also observed in up to $10 \%$ of healthy control individuals, on intracellular $\beta$-adrenergic signaling in cardiomyocytes varies depending on their effect on receptor conformation and its internalization [12]. The binding sites for the pathogenic $\beta 1$-adrenergic receptor antibodies are confined to portions of the extracellular loop domains where they induce agonist-like effects finally leading to apoptosis [29]. The presence of stimulating $\beta 1$-adrenergic auto-antibodies was reported to independently predict the increased all-cause and cardiovascular mortality risk in a prospective study following patients with DCM over 10 years [129]. The prevalence of stimulating $\beta 1$-adrenergic auto-antibodies was $26 \%$ of patients with DCM in this cohort.

Several related studies have demonstrated that immunoadsorption induces improvement of left ventricular function in patients with DCM $[39,125,126]$. It was also found that patients with auto-antibodies that induce cardiodepressant effects in vitro benefit most from this treatment $[3,128]$. Immuno-adsorption with subsequent immunoglobulin substitution led to a reduction in the number of leukocytes and HLA class II expression in the myocardium of DCM patients, indicating that inflammatory activity within the myocardium is in fact reduced by treatment, whereas the extent of fibrosis was unchanged [127]. These promising results stimulated the design of a larger randomized trial on immune-adsorption which is currently underway (NCT00558584). As a different approach, there is another ongoing clinical trial evaluating a blocking peptide against stimulating $\beta 1$-adrenergic auto-antibodies in DCM patients (COR-1 NCT01391507) [105].

Immunoglobulins

A wide array of potential immuno-modulating effects has been attributed to intravenous immunoglobulins which demonstrated therapeutic efficacy in a variety of diseases with unrelated pathophysiology. However, clinical study results for treating heart failure are ambiguous. A small randomized trial in patients with symptomatic heart failure demonstrated a change in the balance between inflammatory and anti-inflammatory cytokines by immunoglobulin treatment. This effect was significantly correlated with an improvement in LVEF [52]. Another small randomized trial proved no effect of immunoglobulin treatment [101].

The underlying biological mechanism for the potential beneficial effects of immunoglobulins in DCM remains to be determined. A comprehensive overview of potential mechanism was recently provided by Gelfand [49]. Neutralization of auto-antibodies is one mechanism often discussed to contribute to the beneficial effect of immunoglobulins in auto-immune disease. However, a 
study in patients with DCM and ischemic cardiomyopathy found that intravenous immunoglobulins did not neutralize $\beta 1$-adrenergic auto-antibodies [86]. Interpretation of the heterogenous study results is especially hampered by the fact that in most studies no comprehensive histological information from endomyocardial biopsies of all participants was available. Of note, there is a high rate of viral persistence in the myocardium of patients with idiopathic DCM [92]. Elimination of virus persistence was further demonstrated to improve the prognosis in a relatively small cohort of DCM patients [81]. Immunoglobulins have especially been shown to possess both anti-inflammatory and antiviral effects in experimental myocarditis [130]. This led to clinical evaluation of intravenous immunoglobulins for the treatment of viral cardiomyopathy. The most comprehensive current European Study on the Epidemiology and Treatment of Cardiac Inflammatory Disease (ESETCID) trial includes an elaborate treatment protocol treating cytomegalovirus, adeno-, and Parvo B19 positive inflammatory DCM patients with immunoglobulins [70, 95]. The final publication of the results of the trial is still pending.

Given the efficacy of immunoglobulins in attenuating virus replication in myocardium, it might thus be the case that the high prevalence of latent virus infection in the myocardium of DCM patients contributes to the positive effects of immunoglobulins in heterogeneous populations of DCM patients included in the above-mentioned trials.

\section{Bone marrow derived cells/progenitor cells}

The field of therapeutic stem cell therapy has made great advance in the last years due to a number of clinical studies which are underway or just have been completed [58]. Most animal studies could not attribute the observed functional effects to regeneration via local engraftment and proliferation. Instead, paracrine effects of the transferred cells are generally believed to play a central role. Immunomodulation by these cells might contribute to the overall beneficial effects of a variety of cell types. Especially for mesenchymal stem cells, manifold immuno-modulating properties have been described in this context [145]. Others have speculated that apoptotic cells, within the transferred cell preparations inducing immunosuppression, might play an important role [64, 90, 139]. This hypothesis would help explaining, why such a great variety of unrelated cell types produced an effect in experimental studies.

Most clinical trials were designed to improve repair/ regeneration of the injured heart in the setting of myocardial infarction, while few studies yet addressed chronic heart failure patients.

The TOPCARE-CHD trial tested intracoronary treatment with either bone marrow cells or peripheral progenitor cells in a crossover design in patients with chronic ischemic heart failure. Transplantation of bone marrow cells was associated with moderate but significant improvement in the left ventricular ejection fraction after 3 months [7] and even improved survival in a registrybased analysis [6].

Another group reported similar promising results of intramyocardial delivery of bone marrow cells in chronic myocardial infarction and advanced chronic heart failure patients [111].

It was speculated that progenitor cell therapy might be more promising in non-ischemic heart failure patients, as the functional capacity of endogenous progenitor cells is more severely impaired in patients with ischemic cardiomyopathy than in DCM patients [137]. In the transplantation of progenitor cells and functional regeneration enhancement pilot trial in patients with non-ischemic dilated cardiomyopathy (TOPCARE-DCM) trial, autologous intracoronary bone marrow application resulted in significant improvement in LVEF at 1 year [41]. However, as it was often the case in progenitor cell trials, no adequate control group was studied in parallel in this pilot trial.

Recently, 5-year follow-up data of a well-designed, albeit not placebo-controlled and not double-blinded, randomized study investigating the long-term effects of intracoronary administration of G-CSF-mobilized CD34 ${ }^{+}$ stem cells in patients with DCM were reported. During the follow-up period, cell therapy was associated with a moderate but significant improvement in cardiac function (mean increase of EF $5.7 \%$ ), coming along with an improved exercise capacity and even decreased mortality [148]. Interestingly, homing efficiency correlated with changes in EF indicating that transplanted cells elicited local effects in myocardium rather than inducing a systemic, e.g., immuno-modulating, effect.

However, none of the trials in chronic heart failure patients deeply assessed parameters of immune activation. Therefore, the contribution of putative immuno-modulatory effects of transferred cell preparations cannot be determined yet.

\section{New translational targets}

There is a great variety of potential therapeutic targets in the field of pro-inflammatory signaling in heart failure. Perhaps, most experimental evidence has accumulated in experimental models of post-myocardial infarction heart failure concerning toll-like receptor and intracellular $\mathrm{NF \kappa B}$ signaling (for review [42-44, 68]). However, the universal role of this system in innate immunity might induce unforeseeable side effects, especially concerning susceptibility to infection and auto-immunity. Thus, despite a good understanding of this 
signaling system, no therapeutic trial addressing chronic heart failure has been launched so far in this field.

Besides numerous signaling molecules like cytokines, chemokines, and their related receptors which have meanwhile been identified and targeted in animal studies two novel targets should be highlighted here.

\section{Complement}

Complement is activated during acute and chronic cardiac injury in different animal models. Michael Carroll's group demonstrated complement activation by ischemia/reperfusion in different organs by a single IgM clone that recognizes a neo-epitope on hypoxic cells $[65,159]$. This clone is produced by a subset of B-lymphocytes called B-1 cells, the major source for natural IgM antibodies. Carroll's group subsequently identified the relevant antigen as nonmuscle myosin heavy chain II which becomes accessible to natural IgM after cell injury [159]. No experimental data are published on the role of natural IgM in chronic heart failure yet.

Glycoprotein-130 (gp130) is the common receptor of IL-6, which is elevated in patients with chronic heart failure [5]. Cardiomyocyte-specific gp130 mutant mice have a normal myocardial phenotype at baseline, but increased mortality and development of heart failure after experimental myocardial infarction. This was associated with increased expression of complement-activating mannose-binding lectin (MBL) [62]. This animal model suggested a link between IL- 6 and chronic myocardial injury induced by complement activation.

MBL and IgMs are independent trigger mechanisms for initiating the complement cascade. Both pathways converge on the activation of complement component $\mathrm{C} 3$ into cleaved C3a. Mice deficient for either $\mathrm{C} 3$ or the membrane receptor for $\mathrm{C} 3 \mathrm{a}(\mathrm{C} 3 \mathrm{aR})$ is protected against chronic left ventricular remodeling after myocardial infarction (own unpublished results).

Accordingly, a prospective study in a chronic heart failure cohort comprising 182 patients demonstrated that complement activation is strongly linked to the outcome in chronic heart failure. Especially, high levels of activated C3, C3a, predicted cardiovascular events such as hospitalization and mortality [50]. However, studies in CHF patients are lacking yet. There are just clinical data for complement inhibition in the setting of acute ischemia. Whereas $\mathrm{C} 1$ esterase inhibitor treatment showed promising effects in surgically revascularized STEMI patients [38], anti-C5a therapy had no effect in STEMI patients [51].

Therefore, there is a considerable experimental evidence that at least after ischemic myocardial injury, there is an ongoing complement activity in myocardium. Interventions inhibiting complement activation, especially the central component $\mathrm{C} 3 / \mathrm{C} 3$ a may represent a novel target for prevention and treatment of chronic heart failure after large myocardial infarction.

Regulatory T-cells

Most immuno-mechanisms studied in chronic heart failure till date address innate immunity, whereas adaptive immune mechanisms have gained much less interest so far. Recently, $\mathrm{CD}^{+}{ }^{+}$regulatory $\mathrm{T}$-cells came especially into focus.

Regulatory $\mathrm{CD} 4^{+} \mathrm{T}$-cells comprise a subset of thymusderived T-cells which are characterized by intracellular expression of the transcription factor Foxp3 [115]. By means of cell surface staining for FACS analysis they are often defined as $\mathrm{CD}^{+} \mathrm{CD} 25^{+} \mathrm{CD} 127^{\text {low }} \mathrm{CD} 3^{+}$T-cells. Regulatory T-cells are well known for preventing autoreactive immune responses which are associated with chronic myocardial diseases, such as auto-antibody formation [19]. As discussed below, there is further evidence from animal studies that they modulate fibrosis, cardiomyocyte hypertrophy, and monocyte activation in the myocardium, processes which constitute central mechanisms in myocardial remodeling (Fig. 2).

Regulatory $\mathrm{CD}^{+}$T-cells might mediate part of the clinical effect of immuno-modulating therapeutic principles, which was already tested in clinical studies: intravenous immunoglobulins beneficially modulate several unrelated auto-immune diseases. As discussed above, clinical trials indicate that they might also have beneficial

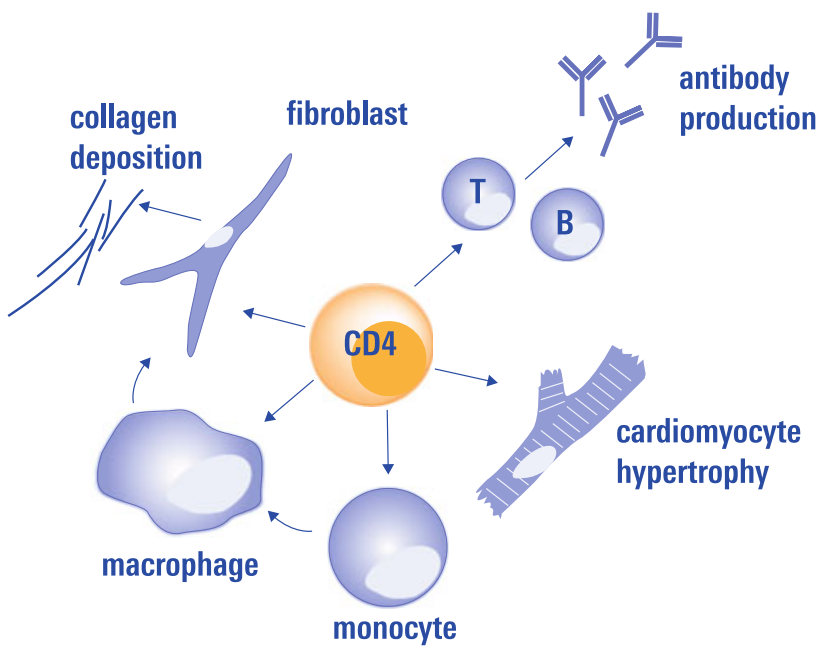

Fig. $2 \mathrm{CD}^{+}$regulatory T-cells modulate the function of T-effector cells and B-cells which leads to e.g., autoantibody production which has been found to contribute to cardiac dysfunction in several heart disease. Besides their classical regulatory role on adaptive immune response they have also been demonstrated to influence monocyte differentiation, which again influences fibrosis, and to attenuate myocardial hypertrophy 
effect in inflammatory cardiomyopathies. It was speculated that sustained peripheral expansion of antigen-specific $\mathrm{CD} 4{ }^{+} \mathrm{CD} 25^{+} \mathrm{Foxp}^{+}$regulatory $\mathrm{T}$-cells might contribute to their therapeutic effect [93].

Besides possible effects by neutralizing autoreactive antibodies, a recent study indicated that immunoadsorption also modifies $\mathrm{T}$ cell-mediated immune reactions. Immuno-adsorption in patients with DCM was associated with a significant increase of regulatory $\mathrm{T}$ cells $\left(\mathrm{CD} 4^{+} \mathrm{CD} 25^{+} \mathrm{CD} 127^{\text {low }}\right)$, and a decrease of activated $\mathrm{T}$ cells $\left(\mathrm{CD}^{+}{ }^{+} \mathrm{CD} 9^{+}\right.$and $\mathrm{CD} 8^{+} \mathrm{CD} 69^{+}$cells and $\mathrm{CD} 28^{+} \mathrm{T}$ cells) [17]. The frequency of circulating regulatory T-cells also correlated with the hemodynamic response to immuno-adsorption [16].

Furthermore, reduced numbers and impaired suppressive function of $\mathrm{CD} 4^{+} \mathrm{CD} 25^{+}$Foxp $3^{+} \mathrm{CD} 127^{\text {low }}$ cells were found in peripheral blood of patients with chronic heart failure [131]. There are also some experimental data indicating, that loss of functional regulatory T-cells is not just an epiphenomenon in chronic heart failure, but might also be relevant for myocardial remodeling in different disease states. We have recently demonstrated that myocardial infarction rapidly induces activation of proliferation of $\mathrm{CD} 4{ }^{+} \mathrm{CD} 25^{+}$Foxp $^{+}$T-cells in heart draining lymph nodes [66]. Our data indicate that the recognition of an antigen released from the injured myocardium is responsible for this activation process. Transfer of $\mathrm{CD} 4{ }^{+} \mathrm{CD} 25^{+} \mathrm{T}$-cells was further reported to attenuate myocardial remodeling after experimental myocardial infarction in mice [97, 132]. Another group reported that transfer of $\mathrm{CD} 4{ }^{+} \mathrm{CD} 25^{+}$cells ameliorates cardiac hypertrophy and fibrosis in response to angiotensin II [84]. Of note, this was also associated with an amelioration of arrhythmogenic electric remodeling.

Therefore, therapeutic expansion and activation of regulatory T-cells might tackle several immunological mechanisms contributing to the heart failure syndrome: mitigation of the expression of pro-inflammatory cytokines, suppression of auto-antibody production, and modification of recruitment, and differentiation of monocytic heart infiltrating cells contributing to both tissue repair and remodeling (own unpublished data).

Besides transfer of autologous, ex vivo enriched regulatory T-cells, therapeutic expansion/activation in vivo might be more promising [31, 114]. Mucosal application of antigens is able to potently induce regulatory $\mathrm{T}$-cells with specificity against it. Thus, mucosal administration of proteins induces secretion of anti-inflammatory cytokines, such as IL-10 at the anatomical site where the protein localizes. Frenkel et al. [46] have demonstrated that nasal application of troponin reduces infarct size after myocardial ischemiareperfusion. This principle has not yet been tested in chronic heart failure, but might be a rather specific means of tuning immunity within the diseased myocardium.
Histone deacetylases (HDACs) catalyze the removal of acetyl groups from a variety of proteins. HDACs have been studied mainly in the context of chromatin, where they contribute to epigenetic regulation of gene expression by deacetylating nucleosomal histones. HDAC inhibitors stimulate $\mathrm{T}_{\text {reg }}$ production by promoting acetylation of the Foxp3 transcription factor, which is a key regulator of $\mathrm{T}_{\text {reg }}$ differentiation [149]. On the other hand, HDAC inhibitors beneficially affect myocardial remodeling, especially pathological hypertrophy in animal models [98]. The mechanism by which they do that is not quite clear, but induction of regulatory T-cells might significantly contribute to their effect. Therefore, this kind of drug might constitute a very interesting new therapeutic principle for targeting both inflammation and pathological fibrosis and hypertrophy in the context of chronic heart failure.

\section{Conclusion}

Most completed trials on immuno-modulatory treatments were rather small including less than 100 patients/group. Data from randomized, placebo-controlled studies including more than 1,000 patients exist for TNF- $\alpha$ antagonists [25, 96]. The rosuvastatin trials, GISSI [134] and CORONA [77], as well as the ACCLAIM trial studying immuno-modulation by ex vivo modified autologous blood [147], also included more than 1,000 patients. All these chronic heart failure trials failed to demonstrate a benefit by meeting pre-specified endpoints. The sole large-scale randomized trial that was able to reveal some benefit was GISSI-HF which found a moderate, albeit significant benefit of $\omega-3$ PUFA in addition to standard heart failure medication including a reduction in total mortality [133].

Why did so many clinical trials, which were all launched on the basis of promising experimental data, show no additional benefit to current standard heart failure therapy?

As one hypothetical explanation, it must be mentioned here that standard drugs addressing neuro-humoral activation, which are obligatory co-medication in current heart failure trials also might have relevant effects on inflammatory activation. Especially ACE inhibitors have immuno-modulatory properties, as components of the renin-angiotensin-aldosterone system are expressed on leukocytes. Especially, the angiotensin-aldosterone system in T-cells came recently into the focus. T-cells contain an endogenous renin-angiotensin system that modulates proinflammatory T-cell function [63]. Blocking angiotensinconverting enzymes on the other hand induces regulatory $\mathrm{CD} 4{ }^{+}$Foxp $3^{+}$T-cells which have the ability to dampen pathological inflammation and auto-immune by a variety of mechanisms [110]. Accordingly, it was reported that 
enalapril decreases IL-6 levels in patients with chronic systolic heart failure [53]. It remains unclear, however, whether this effect is due to a direct immuno-modulatory effect of the ACE inhibitor or rather a consequence of the improved overall hemodynamic and functional status under this medication. This relates to a central, yet unresolved question in the field, whether inflammation in heart failure is causative for or merely a consequence of heart failure.

One might ask whether there is still a justifiable rationale for conduction of future clinical trials targeting inflammation as adjunct to our current pharmacological heart failure therapy. In our opinion, there is good experimental evidence that inflammation causally contributes to myocardial dysfunction and, thus, still constitutes a reasonable and promising therapeutic target, but some questions have to be carefully addressed before designing a clinical trial.

First, which patients are best candidates for immunomodulating treatment modalities? The hope to find a therapeutic principle that fits in all clinical scenarios of heart failure seems to be more and more unrealistic. It might be more promising in the future to individually characterize the immunologic status of a patient to decide whether he might benefit from the targeted immuno-modulation at the present time. Especially in patients with idiopathic DCM, this will have to include endomyocardial biopsies to gain more insights to define the present status of intramyocardial inflammatory activity and, especially, to exclude ongoing viral activity. Infectious (especially virus induced) cardiomyopathy might become accessible to a completely different treatment in the future. Immunoadsorption in patients with auto-antibodies, which have been evaluated for their cardio-specificity and toxicity, exemplifies such a first individualized approach [128]. Complementary to the still underused endomyocardial biopsy-based analyses, which have inherent limitations mainly due to sampling errors, there is an urgent need for identifying novel biomarkers or imaging modalities to identify CHF patients who could benefit from immunomodulation.

Monitoring of systemic, i.e., serum parameters of inflammation, especially cytokines, does likely not reflect myocardial inflammation, but is rather a marker of the overall clinical status. Therefore, one cannot conclude from the currently available serum parameters, which are often the only available biomaterial to monitor immunity in clinical studies, on the local effect on myocardial inflammation. Thus, at the moment, the real biological effect of immuno-modulating therapies, putatively beneficially influencing myocardial inflammation, cannot readily become assessed in clinical studies.

As a different approach, as opposed to CHF patients, the wound healing phase after an acute myocardial infarction, which is the most important cause for heart failure in the Western word, might constitute another attractive phase for preventive immuno-modulation [42]. Experimental animal studies indicate that there might be an early window for intervention to tune the immunological response to cardiac injury limiting infarct expansion and induction of ongoing remodeling in the remote myocardium.

Second, how can we better identify immuno-modulating treatment principles tested in animal models to be suited for further translational clinical evaluation? Here, preclinical testing of therapeutic modalities warrants more attention. Several treatment modalities went into clinical trials, mainly on the basis of promising effects in rodent models, indicating that immuno-modulation, as evidenced e.g., by cytokine expression profiling or genetic lack/gain of function studies, might be causative. Here, we have to pay more attention on the transferability of immunological phenomena from small animal models to man. This does not only relate to the estimation of the putative therapeutic impact, but also to potential side effects. In addition, before going into man for phase I/II trials, large-animal studies have to be advocated. However, even a very good understanding of the biological mechanism of an immunomodulating therapeutic tested in different species does not prevent from unexpected effects in man which can, at best lead to lack of efficacy, but also to deleterious side effects [71].

Also essential, but widely underestimated, factors like age [11], co-medication, comorbidity, and last but not least, gender have to be drawn into consideration as much as possible in animal studies before thinking about clinical trials.

Therefore, we pledge for even greater effort spent on translational cardio-immunological research which goes beyond phenomenological description of beneficial effects on myocardial function and remodeling and its association with parameters of inflammation. Given the inherent limitation to monitor the systemic and, especially local immunological processes within the myocardium in patients, a deep understanding of the biological effects of a therapeutic principle in different experimental models is vital before starting clinical studies.

In addition, in this context, as many therapeutically principles have only been tested in the chronic myocardial infarction heart failure mouse model, other models of chronic heart failure, especially models of genetic and inflammatory cardiomyopathies, should receive more interest in the future.

Summing up the current evidence from both experimental and clinical studies discussed here, we would like to conclude that inflammation is a promising therapeutic target in the setting of CHF. Current state of evidence from 
Table 1 Randomized clinical studies evaluating immuno-modulating/anti-inflammatory treatments in CHF patients as discussed in the manuscript

\begin{tabular}{|c|c|c|c|c|c|c|}
\hline Therapeutic intervention & Study & $\begin{array}{l}\text { Patient } \\
\text { number }\end{array}$ & $\begin{array}{l}\text { Mean } \\
\text { EF }\end{array}$ & $\begin{array}{l}\text { NYHA } \\
\text { status }\end{array}$ & Etiology & Main outcome \\
\hline \multicolumn{7}{|l|}{ TNF- $\alpha$ binding } \\
\hline \multirow[t]{3}{*}{ Etanercept } & {$[32]$} & 18 & $23 / 29 \%$ & III & Mixed & Improved functional parameters and $\mathrm{EF}$ \\
\hline & {$[15]$} & 47 & $16-21 \%$ & III-IV & Mixed & \\
\hline & [96] & 2,048 & $22-24 \%$ & III-IV & Mixed & Improved $\mathrm{EF}$ and remodeling parameters \\
\hline \multirow[t]{2}{*}{ Infliximab } & {$[25]$} & 150 & $23-25 \%$ & III-IV & Mixed & $\begin{array}{l}\text { Combined analysis of RECOVER and } \\
\text { RENAISSANCE trials: no effect on clinical } \\
\text { composite endpoint }\end{array}$ \\
\hline & & & & & & $\begin{array}{l}\text { No clinical improvement, combined risk of death } \\
\text { from any cause or hospitalization for heart } \\
\text { failure increased in subgroup }\end{array}$ \\
\hline Prednisone & {$[108]$} & 102 & $18 \%$ & nd & DCM & Transient improvement in EF \\
\hline \multirow[t]{2}{*}{ Prednisone + azathioprine } & {$[150]$} & 202 & $24 \%$ & II-IV & DCM & $\begin{array}{l}\text { Improved secondary endpoint of LV volume and } \\
\text { EF }\end{array}$ \\
\hline & {$[48]$} & 85 & $27 \%$ & II-IV & $\begin{array}{l}\text { Virus-negative } \\
\text { myocarditis }\end{array}$ & Improved EF and NYHA class \\
\hline Thalidomide & {$[55]$} & 56 & $25 \%$ & II-III & Mixed & Improved EF \\
\hline \multirow[t]{2}{*}{ Rosuvastatin } & {$[77]$} & 5,011 & $31 / 33 \%$ & II-IV & Mixed & No effect of primary combined endpoint \\
\hline & {$[134]$} & 4,631 & $33 \%$ & II-IV & Mixed & No effect of primary combined endpoint \\
\hline \multirow[t]{5}{*}{ Pentoxifylline } & [119] & 39 & $24 / 25 \%$ & II-III & $\mathrm{DCM}$ & Improved functional status after 6 months \\
\hline & {$[120]$} & 49 & $23 \%$ & II-III & DCM & Improved functional class, and $\mathrm{EF}$ \\
\hline & {$[122]$} & 28 & $25 / 22 \%$ & II-III & $\mathrm{DCM}$ & Improved $\mathrm{EF}$ and functional status \\
\hline & [123] & 18 & $13 / 16 \%$ & IV & DCM & Improved EF \\
\hline & {$[124]$} & 38 & $23 / 27 \%$ & II-III & ICM & Functional improvement \\
\hline $\begin{array}{l}\text { Isosorbide } \\
\text { dinitrate }+ \text { hydralazine }\end{array}$ & {$[135]$} & 1,050 & $24 \%$ & III-IV & Mixed & $\begin{array}{l}\text { Improved composite endpoint in African- } \\
\text { Americans. Study terminated prematurely for } \\
\text { early benefit }\end{array}$ \\
\hline Vitamin E & {$[74]$} & 56 & $23 \%$ & III-IV & Mixed & $\begin{array}{l}\text { No clinical improvement, no effect on markers } \\
\text { of oxidative stress after } 12 \text { weeks on treatment }\end{array}$ \\
\hline $\begin{array}{l}\text { Autologous modified } \\
\text { blood }\end{array}$ & {$[144]$} & 75 & $22 \%$ & III-IV & Mixed & $\begin{array}{l}\text { Reduced mortality and risk of hospitalization } \\
\text { after } 6 \text { months }\end{array}$ \\
\hline \multirow[t]{2}{*}{ Polyunsaturated fatty acids } & {$[133]$} & 7,046 & $33 \%$ & II-IV & Mixed & Improved composite endpoint \\
\hline & [104] & 43 & $24 \%$ & III-IV & Non-ICM & Dose-dependent improved EF \\
\hline Immuno-adsorption & {$[126]$} & 22 & $28 / 27 \%$ & III-IV & DCM & Improved EF, without control group \\
\hline \multirow[t]{2}{*}{ Immunoglobulins } & {$[52]$} & 40 & $26 / 28 \%$ & II-III & Mixed & Improved EF \\
\hline & [101] & 62 & $25 \%$ & I-IV & $\begin{array}{l}\text { DCM, } \\
\text { myocarditis }\end{array}$ & No change in EF \\
\hline \multirow[t]{3}{*}{$\begin{array}{l}\text { Intracoronary progenitor } \\
\text { cells }\end{array}$} & [7] & 92 & $\begin{array}{r}43 / 39 / \\
41 \%\end{array}$ & I-III & ICM & $\begin{array}{l}\text { Improved } \mathrm{EF} 3 \text { months after infusion of bone } \\
\text { marrow derived cells }\end{array}$ \\
\hline & [111] & 109 & $27 \%$ & II-IV & ICM & $\begin{array}{l}\text { Improved functional status and EF } 12 \text { months } \\
\text { after infusion of bone marrow derived cells }\end{array}$ \\
\hline & [148] & 110 & $24 / 26 \%$ & III & $\mathrm{DCM}$ & $\begin{array}{l}\text { Improved functional status and EF after } 5 \text { years } \\
\text { of infusion of CD } 34^{+} \text {cells }\end{array}$ \\
\hline
\end{tabular}

If mean $\mathrm{EF}$ was not equal, $\mathrm{EF}$ for placebo/treatment groups were indicated

$n d$ not determined, ICM ischemic cardiomyopathy, DCM dilative cardiomyopathy

clinical trials indicates that unspecific immuno-modulation, e.g., by steroids or immuno-adsorption, holds some promise especially in the "orphan" field of idiopathic/ inflammatory, non-viral DCM (see Table 1). Thus, we can await even greater benefit from more targeted or even individualized treatment modalities which are eagerly awaited in the field as complementary therapeutic means to our current heart failure drugs. 
Acknowledgments We thank Mrs. Susanne Ripberger for preparing the figures. This work was supported by Grants from the Bundesministerium für Bildung und Forschung (BMBF01 EO1004) (S.F.) and by the Deutsche Forschungsgemeinschaft, SFB688 TP A10 (S.F.).

Conflict of interest On behalf of all authors, the corresponding author states that there is no conflict of interest.

Open Access This article is distributed under the terms of the Creative Commons Attribution License which permits any use, distribution, and reproduction in any medium, provided the original author(s) and the source are credited.

\section{References}

1. GISSI Prevenzione Investigators (1999) Dietary supplementation with n-3 polyunsaturated fatty acids and vitamin $\mathrm{E}$ after myocardial infarction: results of the GISSI-Prevenzione trial. Gruppo Italiano per lo Studio della Sopravvivenza nell'Infarto miocardico. Lancet 354:447-455. pii:S0140673699070725

2. Abel ED, Litwin SE, Sweeney G (2008) Cardiac remodeling in obesity. Physiol Rev 88:389-419. doi:10.1152/physrev. 00017.2007

3. Ameling S, Herda LR, Hammer E, Steil L, Teumer A, Trimpert C, Dorr M, Kroemer HK, Klingel K, Kandolf R, Volker U, Felix SB (2012) Myocardial gene expression profiles and cardiodepressant autoantibodies predict response of patients with dilated cardiomyopathy to immunoadsorption therapy. Eur Heart $\mathbf{J}$ 34:666-675. doi:10.1093/eurheartj/ehs330

4. Anker SD, Coats AJ (2002) How to RECOVER from RENAISSANCE? The significance of the results of RECOVER, RENAISSANCE, RENEWAL and ATTACH. Int $\mathrm{J}$ Cardiol 86:123-130

5. Askevold ET, Nymo S, Ueland T, Gravning J, Wergeland R, Kjekshus J, Yndestad A, Cleland JG, McMurray JJ, Aukrust P, Gullestad L (2013) Soluble glycoprotein 130 predicts fatal outcomes in chronic heart failure: analysis from the Controlled Rosuvastatin Multinational Trial in Heart Failure (CORONA). Circ Heart Fail 6:91-98. doi:10.1161/CIRCHEARTFAILURE. 112.972653

6. Assmus B, Fischer-Rasokat U, Honold J, Seeger FH, Fichtlscherer S, Tonn T, Seifried E, Schachinger V, Dimmeler S, Zeiher AM (2007) Transcoronary transplantation of functionally competent BMCs is associated with a decrease in natriuretic peptide serum levels and improved survival of patients with chronic postinfarction heart failure: results of the TOPCARECHD Registry. Circ Res 100:1234-1241. doi:10.1161/01.RES. 0000264508.47717.6b

7. Assmus B, Honold J, Schachinger V, Britten MB, FischerRasokat U, Lehmann R, Teupe C, Pistorius K, Martin H, Abolmaali ND, Tonn T, Dimmeler S, Zeiher AM (2006) Transcoronary transplantation of progenitor cells after myocardial infarction. N Engl J Med 355:1222-1232. doi:10.1056/NEJ Moa051779

8. Aukrust P, Ueland T, Lien E, Bendtzen K, Muller F, Andreassen AK, Nordoy I, Aass H, Espevik T, Simonsen S, Froland SS, Gullestad L (1999) Cytokine network in congestive heart failure secondary to ischemic or idiopathic dilated cardiomyopathy. Am J Cardiol 83:376-382 (pii:S0002-9149(98)00872-8)

9. Bahrmann P, Hengst UM, Richartz BM, Figulla HR (2004) Pentoxifylline in ischemic, hypertensive and idiopathic-dilated cardiomyopathy: effects on left-ventricular function, inflammatory cytokines and symptoms. Eur J Heart Fail 6:195-201. doi: 10.1016/j.ejheart.2003.09.005
10. Bianchi ME (2007) DAMPs, PAMPs and alarmins: all we need to know about danger. J Leukoc Biol 81:1-5. doi:10.1189/jlb. 0306164

11. Boengler K, Schulz R, Heusch G (2009) Loss of cardioprotection with ageing. Cardiovasc Res 83:247-261. doi:10.1093/cvr/ cvp033

12. Bornholz B, Weidtkamp-Peters S, Schmitmeier S, Seidel CA, Herda LR, Felix SB, Lemoine H, Hescheler J, Nguemo F, Schafer C, Christensen MO, Mielke C, Boege F (2013) Impact of human autoantibodies on beta1-adrenergic receptor conformation, activity, and internalization. Cardiovasc Res 97:472480. doi: $10.1093 / \mathrm{cvr} / \mathrm{cvs} 350$

13. Borthwick LA, Wynn TA, Fisher AJ (2012) Cytokine mediated tissue fibrosis. Biochim Biophys Acta. doi:10.1016/j.bbadis. 2012.09.014

14. Bozkurt B, Kribbs SB, Clubb FJ Jr, Michael LH, Didenko VV, Hornsby PJ, Seta Y, Oral H, Spinale FG, Mann DL (1998) Pathophysiologically relevant concentrations of tumor necrosis factor-alpha promote progressive left ventricular dysfunction and remodeling in rats. Circulation 97:1382-1391

15. Bozkurt B, Torre-Amione G, Warren MS, Whitmore J, Soran OZ, Feldman AM, Mann DL (2001) Results of targeted antitumor necrosis factor therapy with etanercept (ENBREL) in patients with advanced heart failure. Circulation 103:10441047

16. Bulut D, Creutzenberg G, Mugge A (2012) The number of regulatory $\mathrm{T}$ cells correlates with hemodynamic improvement in patients with inflammatory dilated cardiomyopathy after immunoadsorption therapy. Scand J Immunol 77:54-61. doi: 10.1111/sji. 12000

17. Bulut D, Scheeler M, Wichmann T, Borgel J, Miebach T, Mugge A (2010) Effect of protein A immunoadsorption on T cell activation in patients with inflammatory dilated cardiomyopathy. Clin Res Cardiol 99:633-638. doi:10.1007/s00392-0100162-6

18. Busquets S, Aranda X, Ribas-Carbo M, Azcon-Bieto J, LopezSoriano FJ, Argiles JM (2003) Tumour necrosis factor-alpha uncouples respiration in isolated rat mitochondria. Cytokine 22:1-4 (pii:S104346660300098X)

19. Bystry RS, Aluvihare V, Welch KA, Kallikourdis M, Betz AG (2001) B cells and professional APCs recruit regulatory T cells via CCL4. Nat Immunol 2:1126-1132. doi:10.1038/ni735

20. Caforio AL, Mahon NG, Baig MK, Tona F, Murphy RT, Elliott PM, McKenna WJ (2007) Prospective familial assessment in dilated cardiomyopathy: cardiac autoantibodies predict disease development in asymptomatic relatives. Circulation 115:76-83. doi:10.1161/CIRCULATIONAHA.106.641472

21. Caforio AL, Mahon NG, McKenna WJ (2006) Clinical implications of anti-cardiac immunity in dilated cardiomyopathy. Ernst Schering Res Found Workshop 55:169-193

22. Caforio AL, Mahon NJ, Tona F, McKenna WJ (2002) Circulating cardiac autoantibodies in dilated cardiomyopathy and myocarditis: pathogenetic and clinical significance. Eur J Heart Fail 4:411-417. doi:S1388984202000107

23. Canton M, Menazza S, Sheeran FL, Polverino de Laureto P, Di Lisa F, Pepe S (2011) Oxidation of myofibrillar proteins in human heart failure. J Am Coll Cardiol 57:300-309. doi: 10.1016/j.jacc.2010.06.058

24. Canton M, Skyschally A, Menabo R, Boengler K, Gres P, Schulz R, Haude M, Erbel R, Di Lisa F, Heusch G (2006) Oxidative modification of tropomyosin and myocardial dysfunction following coronary microembolization. Eur Heart $\mathbf{J}$ 27:875-881. doi:10.1093/eurheartj/ehi751

25. Chung ES, Packer M, Lo KH, Fasanmade AA, Willerson JT (2003) Randomized, double-blind, placebo-controlled, pilot trial of infliximab, a chimeric monoclonal antibody to tumor necrosis 
factor-alpha, in patients with moderate-to-severe heart failure: results of the anti-TNF therapy against congestive heart failure (ATTACH) trial. Circulation 107:3133-3140

26. Cicoira M, Bolger AP, Doehner W, Rauchhaus M, Davos C, Sharma R, Al-Nasser FO, Coats AJ, Anker SD (2001) High tumour necrosis factor-alpha levels are associated with exercise intolerance and neurohormonal activation in chronic heart failure patients. Cytokine 15:80-86. doi:10.1006/cyto.2001.0918

27. Cooper LT Jr (2009) Myocarditis. N Engl J Med 360:15261538. doi:10.1056/NEJMra0800028

28. Corsten MF, Schroen B, Heymans S (2012) Inflammation in viral myocarditis: friend or foe? Trends Mol Med 18:426-437. doi:10.1016/j.molmed.2012.05.005

29. Dandel M, Wallukat G, Potapov E, Hetzer R (2012) Role of beta(1)-adrenoceptor autoantibodies in the pathogenesis of dilated cardiomyopathy. Immunobiology 217:511-520. doi:10. 1016/j.imbio.2011.07.012

30. Dangas G, Konstadoulakis MM, Epstein SE, Stefanadis CI, Kymionis GD, Toutouza MG, Liakos C, Sadaniantz A, Cohen AM, Chesebro JH, Toutouzas PK (2000) Prevalence of autoantibodies against contractile proteins in coronary artery disease and their clinical implications. Am J Cardiol 85:870-872 (A876, A879, pii:S0002914999008838)

31. Daniele N, Scerpa MC, Landi F, Caniglia M, Miele MJ, Locatelli F, Isacchi G, Zinno F (2011) T(reg) cells: collection, processing, storage and clinical use. Pathol Res Pract 207:209-215. doi:10.1016/j.prp.2011.02.003

32. Deswal A, Bozkurt B, Seta Y, Parilti-Eiswirth S, Hayes FA, Blosch C, Mann DL (1999) Safety and efficacy of a soluble P75 tumor necrosis factor receptor (Enbrel, etanercept) in patients with advanced heart failure. Circulation 99:3224-3226

33. Deswal A, Petersen NJ, Feldman AM, Young JB, White BG, Mann DL (2001) Cytokines and cytokine receptors in advanced heart failure: an analysis of the cytokine database from the Vesnarinone trial (VEST). Circulation 103:2055-2059

34. Dinh W, Futh R, Nickl W, Krahn T, Ellinghaus P, Scheffold T, Bansemir L, Bufe A, Barroso MC, Lankisch M (2009) Elevated plasma levels of TNF-alpha and interleukin-6 in patients with diastolic dysfunction and glucose metabolism disorders. Cardiovasc Diabetol 8:58. doi:10.1186/1475-2840-8-58

35. Dorge H, Schulz R, Belosjorow S, Post H, van de Sand A, Konietzka I, Frede S, Hartung T, Vinten-Johansen J, Youker KA, Entman ML, Erbel R, Heusch G (2002) Coronary microembolization: the role of TNF-alpha in contractile dysfunction. J Mol Cell Cardiol 34:51-62. doi:10.1006/jmcc.2001.1489

36. Fairweather D, Kaya Z, Shellam GR, Lawson CM, Rose NR (2001) From infection to autoimmunity. J Autoimmun 16:175-186. doi:10.1006/jaut.2000.0492

37. Falcao-Pires I, Palladini G, Goncalves N, van der Velden J, Moreira-Goncalves D, Miranda-Silva D, Salinaro F, Paulus WJ, Niessen HW, Perlini S, Leite-Moreira AF (2011) Distinct mechanisms for diastolic dysfunction in diabetes mellitus and chronic pressure-overload. Basic Res Cardiol 106:801-814. doi: 10.1007/s00395-011-0184-x

38. Fattouch K, Bianco G, Speziale G, Sampognaro R, Lavalle C, Guccione F, Dioguardi P, Ruvolo G (2007) Beneficial effects of $\mathrm{C} 1$ esterase inhibitor in ST-elevation myocardial infarction in patients who underwent surgical reperfusion: a randomised double-blind study. Eur J Cardiothorac Surg 32:326-332. doi: 10.1016/j.ejcts.2007.04.038

39. Felix SB, Staudt A, Landsberger M, Grosse Y, Stangl V, Spielhagen T, Wallukat G, Wernecke KD, Baumann G, Stangl K (2002) Removal of cardiodepressant antibodies in dilated cardiomyopathy by immunoadsorption. J Am Coll Cardiol 39:646-652. doi:S0735109701017946
40. Ferdinand KC (2007) African American heart failure trial: role of endothelial dysfunction and heart failure in African Americans. Am J Cardiol 99:3D-6D. doi:10.1016/j.amjcard.2006.12.013

41. Fischer-Rasokat U, Assmus B, Seeger FH, Honold J, Leistner D, Fichtlscherer S, Schachinger V, Tonn T, Martin H, Dimmeler S, Zeiher AM (2009) A pilot trial to assess potential effects of selective intracoronary bone marrow-derived progenitor cell infusion in patients with nonischemic dilated cardiomyopathy: final 1-year results of the transplantation of progenitor cells and functional regeneration enhancement pilot trial in patients with nonischemic dilated cardiomyopathy. Circ Heart Fail 2:417-423. doi:10.1161/CIRCHEARTFAILURE.109.855023

42. Frantz S, Bauersachs J, Ertl G (2009) Post-infarct remodelling: contribution of wound healing and inflammation. Cardiovasc Res 81:474-481. doi:10.1093/cvr/cvn292

43. Frantz S, Ertl G, Bauersachs J (2007) Mechanisms of disease: toll-like receptors in cardiovascular disease. Nat Clin Pract Cardiovasc Med 4:444-454. doi:10.1038/ncpcardio0938

44. Frantz S, Ertl G, Bauersachs J (2008) Toll-like receptor signaling in the ischemic heart. Front Biosci 13:5772-5779. doi: 3114

45. Frantz S, Hu K, Bayer B, Gerondakis S, Strotmann J, Adamek A, Ertl G, Bauersachs J (2006) Absence of NF-kappaB subunit p50 improves heart failure after myocardial infarction. FASEB J 20:1918-1920. doi:10.1096/fj.05-5133fje

46. Frenkel D, Pachori AS, Zhang L, Dembinsky-Vaknin A, Farfara D, Petrovic-Stojkovic S, Dzau VJ, Weiner HL (2009) Nasal vaccination with troponin reduces troponin specific $\mathrm{T}$-cell responses and improves heart function in myocardial ischemiareperfusion injury. Int Immunol 21:817-829. doi:10.1093/ intimm/dxp051

47. Friedrichs GS, Swillo RE, Jow B, Bridal T, Numann R, Warner LM, Killar LM, Sidek K (2002) Sphingosine modulates myocyte electrophysiology, induces negative inotropy, and decreases survival after myocardial ischemia. J Cardiovasc Pharmacol 39:18-28

48. Frustaci A, Russo MA, Chimenti C (2009) Randomized study on the efficacy of immunosuppressive therapy in patients with virus-negative inflammatory cardiomyopathy: the TIMIC study. Eur Heart J 30:1995-2002. doi:10.1093/eurheartj/ehp249

49. Gelfand EW (2012) Intravenous immune globulin in autoimmune and inflammatory diseases. N Engl J Med 367:2015-2025. doi:10.1056/NEJMra1009433

50. Gombos T, Forhecz Z, Pozsonyi Z, Szeplaki G, Kunde J, Fust G, Janoskuti L, Karadi I, Prohaszka Z (2012) Complement anaphylatoxin $\mathrm{C} 3 \mathrm{a}$ as a novel independent prognostic marker in heart failure. Clin Res Cardiol 101:607-615. doi:10.1007/ s00392-012-0432-6

51. Granger CB, Mahaffey KW, Weaver WD, Theroux P, Hochman JS, Filloon TG, Rollins S, Todaro TG, Nicolau JC, Ruzyllo W, Armstrong PW (2003) Pexelizumab, an anti-C5 complement antibody, as adjunctive therapy to primary percutaneous coronary intervention in acute myocardial infarction: the COMplement inhibition in Myocardial infarction treated with Angioplasty (COMMA) trial. Circulation 108:1184-1190

52. Gullestad L, Aass H, Fjeld JG, Wikeby L, Andreassen AK, Ihlen H, Simonsen S, Kjekshus J, Nitter-Hauge S, Ueland T, Lien E, Froland SS, Aukrust P (2001) Immunomodulating therapy with intravenous immunoglobulin in patients with chronic heart failure. Circulation 103:220-225

53. Gullestad L, Aukrust P, Ueland T, Espevik T, Yee G, Vagelos R, Froland SS, Fowler M (1999) Effect of high- versus low-dose angiotensin converting enzyme inhibition on cytokine levels in chronic heart failure. J Am Coll Cardiol 34:2061-2067 (pii:S0735-1097(99)00495-7) 
54. Gullestad L, Semb AG, Holt E, Skardal R, Ueland T, Yndestad A, Froland SS, Aukrust P (2002) Effect of thalidomide in patients with chronic heart failure. Am Heart J 144:847-850 (pii:S0002870302001965)

55. Gullestad L, Ueland T, Fjeld JG, Holt E, Gundersen T, Breivik K, Folling M, Hodt A, Skardal R, Kjekshus J, Andreassen A, Kjekshus E, Wergeland R, Yndestad A, Froland SS, Semb AG, Aukrust P (2005) Effect of thalidomide on cardiac remodeling in chronic heart failure: results of a double-blind, placebo-controlled study. Circulation 112:3408-3414. doi:10.1161/ CIRCULATIONAHA.105.564971

56. Gullestad L, Ueland T, Vinge LE, Finsen A, Yndestad A, Aukrust P (2012) Inflammatory cytokines in heart failure: mediators and markers. Cardiology 122:23-35. doi:10.1159/000 338166

57. Hare JM, Mangal B, Brown J, Fisher C Jr, Freudenberger R, Colucci WS, Mann DL, Liu P, Givertz MM, Schwarz RP (2008) Impact of oxypurinol in patients with symptomatic heart failure. Results of the OPT-CHF study. J Am Coll Cardiol 51:2301-2309. doi:10.1016/j.jacc.2008.01.068

58. Heusch G (2011) SCIPIO brings new momentum to cardiac cell therapy. Lancet 378:1827-1828. doi:10.1016/S0140-6736(11) 61648-6

59. Heusch G, Schulz R (2011) A radical view on the contractile machinery in human heart failure. $\mathrm{J}$ Am Coll Cardiol 57:310-312. doi:10.1016/j.jacc.2010.06.057

60. Heusch P, Canton M, Aker S, van de Sand A, Konietzka I, Rassaf T, Menazza S, Brodde OE, Di Lisa F, Heusch G, Schulz $R$ (2010) The contribution of reactive oxygen species and p38 mitogen-activated protein kinase to myofilament oxidation and progression of heart failure in rabbits. $\mathrm{Br} \mathrm{J}$ Pharmacol 160:1408-1416. doi:10.1111/j.1476-5381.2010.00793.x

61. Heymans S, Hirsch E, Anker SD, Aukrust P, Balligand JL, Cohen-Tervaert JW, Drexler H, Filippatos G, Felix SB, Gullestad L, Hilfiker-Kleiner D, Janssens S, Latini R, Neubauer G, Paulus WJ, Pieske B, Ponikowski P, Schroen B, Schultheiss HP, Tschope C, Van Bilsen M, Zannad F, McMurray J, Shah AM (2009) Inflammation as a therapeutic target in heart failure? A scientific statement from the Translational Research Committee of the Heart Failure Association of the European Society of Cardiology. Eur J Heart Fail 11:119-129. doi:10.1093/eurjhf/ hfn043

62. Hilfiker-Kleiner D, Shukla P, Klein G, Schaefer A, Stapel B, Hoch M, Muller W, Scherr M, Theilmeier G, Ernst M, Hilfiker A, Drexler H (2010) Continuous glycoprotein-130-mediated signal transducer and activator of transcription-3 activation promotes inflammation, left ventricular rupture, and adverse outcome in subacute myocardial infarction. Circulation 122:145-155. doi:10.1161/CIRCULATIONAHA.109.933127

63. Hoch NE, Guzik TJ, Chen W, Deans T, Maalouf SA, Gratze P, Weyand C, Harrison DG (2009) Regulation of T-cell function by endogenously produced angiotensin II. Am J Physiol Regul Integr Comp Physiol 296:R208-R216. doi:10.1152/ajpregu. 90521.2008

64. Hoetzenecker $\mathrm{K}$, Assinger A, Lichtenauer M, Mildner M, Schweiger T, Starlinger P, Jakab A, Berenyi E, Pavo N, Zimmermann M, Gabriel C, Plass C, Gyongyosi M, Volf I, Ankersmit HJ (2012) Secretome of apoptotic peripheral blood cells (APOSEC) attenuates microvascular obstruction in a porcine closed chest reperfused acute myocardial infarction model: role of platelet aggregation and vasodilation. Basic Res Cardiol 107:292. doi:10.1007/s00395-012-0292-2

65. Hofmann U, Bauersachs J, Frantz S (2010) Nothing but natural: targeting natural IgM in ischaemia/reperfusion injury. Cardiovasc Res 87:589-590. doi:10.1093/cvr/cvq209
66. Hofmann U, Beyersdorf N, Weirather J, Podolskaya A, Bauersachs J, Ertl G, Kerkau T, Frantz S (2012) Activation of $\mathrm{CD} 4+\mathrm{T}$ lymphocytes improves wound healing and survival after experimental myocardial infarction in mice. Circulation 125:1652-1663. doi:10.1161/CIRCULATIONAHA.111.044164

67. Hofmann U, Domeier E, Frantz S, Laser M, Weckler B, Kuhlencordt P, Heuer S, Keweloh B, Ertl G, Bonz AW (2003) Increased myocardial oxygen consumption by TNF-alpha is mediated by a sphingosine signaling pathway. Am J Physiol Heart Circ Physiol 284:H2100-H2105. doi:10.1152/ajpheart. 00888.2002

68. Hofmann U, Ertl G, Frantz S (2011) Toll-like receptors as potential therapeutic targets in cardiac dysfunction. Expert Opin Ther Targets 15:753-765. doi:10.1517/14728222.2011.566560

69. Hori M, Nishida K (2009) Oxidative stress and left ventricular remodelling after myocardial infarction. Cardiovasc Res 81:457-464. doi:10.1093/cvr/cvn335

70. Hufnagel G, Pankuweit S, Richter A, Schonian U, Maisch B (2000) The European Study of Epidemiology and Treatment of Cardiac Inflammatory Diseases (ESETCID). First epidemiological results. Herz 25:279-285

71. Hunig T (2012) The storm has cleared: lessons from the CD28 superagonist TGN1412 trial. Nat Rev Immunol 12:317-318. doi: $10.1038 /$ nri3192

72. Jahns R, Boivin V, Hein L, Triebel S, Angermann CE, Ertl G, Lohse MJ (2004) Direct evidence for a beta 1-adrenergic receptor-directed autoimmune attack as a cause of idiopathic dilated cardiomyopathy. J Clin Investig 113:1419-1429. doi: 10.1172/JCI20149

73. Keith M, Geranmayegan A, Sole MJ, Kurian R, Robinson A, Omran AS, Jeejeebhoy KN (1998) Increased oxidative stress in patients with congestive heart failure. J Am Coll Cardiol 31:1352-1356 (pii:S0735-1097(98)00101-6)

74. Keith ME, Jeejeebhoy KN, Langer A, Kurian R, Barr A, O'Kelly B, Sole MJ (2001) A controlled clinical trial of vitamin E supplementation in patients with congestive heart failure. Am J Clin Nutr 73:219-224

75. Kell R, Haunstetter A, Dengler TJ, Zugck C, Kubler W, Haass M (2002) Do cytokines enable risk stratification to be improved in NYHA functional class III patients? Comparison with other potential predictors of prognosis. Eur Heart J 23:70-78. doi: 10.1053/euhj.2001.2780

76. Kindermann I, Kindermann M, Kandolf R, Klingel K, Bultmann B, Muller T, Lindinger A, Bohm M (2008) Predictors of outcome in patients with suspected myocarditis. Circulation 118:639-648. doi:10.1161/CIRCULATIONAHA.108.769489

77. Kjekshus J, Apetrei E, Barrios V, Bohm M, Cleland JG, Cornel JH, Dunselman P, Fonseca C, Goudev A, Grande P, Gullestad L, Hjalmarson A, Hradec J, Janosi A, Kamensky G, Komajda M, Korewicki J, Kuusi T, Mach F, Mareev V, McMurray JJ, Ranjith $\mathrm{N}$, Schaufelberger M, Vanhaecke J, van Veldhuisen DJ, Waagstein F, Wedel H, Wikstrand J (2007) Rosuvastatin in older patients with systolic heart failure. $N$ Engl $J$ Med 357:2248-2261. doi:10.1056/NEJMoa0706201

78. Kleinbongard P, Heusch G, Schulz R (2010) TNFalpha in atherosclerosis, myocardial ischemia/reperfusion and heart failure. Pharmacol Ther 127:295-314. doi:10.1016/j.pharmthera.2010. 05.002

79. Kubota T, McTiernan CF, Frye CS, Slawson SE, Lemster BH, Koretsky AP, Demetris AJ, Feldman AM (1997) Dilated cardiomyopathy in transgenic mice with cardiac-specific overexpression of tumor necrosis factor-alpha. Circ Res 81:627-635

80. Kuhl U, Pauschinger M, Noutsias M, Seeberg B, Bock T, Lassner D, Poller W, Kandolf R, Schultheiss HP (2005) High prevalence of viral genomes and multiple viral infections in the 
myocardium of adults with "idiopathic" left ventricular dysfunction. Circulation 111:887-893. doi:10.1161/01.CIR. 0000155616.07901.35

81. Kuhl U, Pauschinger M, Schwimmbeck PL, Seeberg B, Lober C, Noutsias M, Poller W, Schultheiss HP (2003) Interferon-beta treatment eliminates cardiotropic viruses and improves left ventricular function in patients with myocardial persistence of viral genomes and left ventricular dysfunction. Circulation 107:2793-2798. doi:10.1161/01.CIR.0000072766.67150.51

82. Kumar A, Paladugu B, Mensing J, Parrillo JE (2007) Nitric oxide-dependent and -independent mechanisms are involved in TNF-alpha-induced depression of cardiac myocyte contractility. Am J Physiol Regul Integr Comp Physiol 292:R1900-R1906. doi:10.1152/ajpregu.00146.2006

83. Kuwahara F, Kai H, Tokuda K, Takeya M, Takeshita A, Egashira K, Imaizumi T (2004) Hypertensive myocardial fibrosis and diastolic dysfunction: another model of inflammation? Hypertension 43:739-745. doi:10.1161/01.HYP.0000118 $584.33350 .7 \mathrm{~d}$

84. Kvakan H, Luft FC, Muller DN (2009) Role of the immune system in hypertensive target organ damage. Trends Cardiovasc Med 19:242-246. doi:10.1016/j.tcm.2010.02.004

85. Kwak B, Mulhaupt F, Myit S, Mach F (2000) Statins as a newly recognized type of immunomodulator. Nat Med 6:1399-1402. doi: $10.1038 / 82219$

86. Larsson L, Mobini R, Aukrust P, Gullestad L, Wallukat G, Waagstein F, Fu M (2004) Beneficial effect on cardiac function by intravenous immunoglobulin treatment in patients with dilated cardiomyopathy is not due to neutralization of antireceptor autoantibody. Autoimmunity 37:489-493. doi:10.1080/ 08916930400011684

87. Lavie CJ, Milani RV, Mehra MR, Ventura HO (2009) Omega-3 polyunsaturated fatty acids and cardiovascular diseases. J Am Coll Cardiol 54:585-594. doi:10.1016/j.jacc.2009.02.084

88. LeGal YM, Morrissey LL (1990) Methylprednisolone interventions in myocardial infarction: a controversial subject. Can J Cardiol 6:405-410

89. Li YY, Feng YQ, Kadokami T, McTiernan CF, Draviam R, Watkins SC, Feldman AM (2000) Myocardial extracellular matrix remodeling in transgenic mice overexpressing tumor necrosis factor alpha can be modulated by anti-tumor necrosis factor alpha therapy. Proc Natl Acad Sci USA 97:12746-12751. doi:10.1073/pnas.97.23.12746

90. Lichtenauer M, Mildner M, Hoetzenecker K, Zimmermann M, Podesser BK, Sipos W, Berenyi E, Dworschak M, Tschachler E, Gyongyosi M, Ankersmit HJ (2011) Secretome of apoptotic peripheral blood cells (APOSEC) confers cytoprotection to cardiomyocytes and inhibits tissue remodelling after acute myocardial infarction: a preclinical study. Basic Res Cardiol 106:1283-1297. doi:10.1007/s00395-011-0224-6

91. Lotze U, Egerer R, Gluck B, Zell R, Sigusch H, Erhardt C, Heim A, Kandolf R, Bock T, Wutzler P, Figulla HR (2010) Low level myocardial parvovirus B19 persistence is a frequent finding in patients with heart disease but unrelated to ongoing myocardial injury. J Med Virol 82:1449-1457. doi:10.1002/jmv.21821

92. Lotze U, Egerer R, Tresselt C, Gluck B, Dannberg G, Stelzner A, Figulla HR (2004) Frequent detection of parvovirus B19 genome in the myocardium of adult patients with idiopathic dilated cardiomyopathy. Med Microbiol Immunol 193:75-82. doi:10.1007/s00430-003-0211-0

93. Maddur MS, Othy S, Hegde P, Vani J, Lacroix-Desmazes S, Bayry J, Kaveri SV (2010) Immunomodulation by intravenous immunoglobulin: role of regulatory $\mathrm{T}$ cells. J Clin Immunol 30(Suppl 1):S4-S8. doi:10.1007/s10875-010-9394-5
94. Mahrholdt H, Wagner A, Deluigi CC, Kispert E, Hager S, Meinhardt G, Vogelsberg H, Fritz P, Dippon J, Bock CT, Klingel K, Kandolf R, Sechtem U (2006) Presentation, patterns of myocardial damage, and clinical course of viral myocarditis. Circulation 114:1581-1590. doi:10.1161/CIRCULATIONAHA. 105.606509

95. Maisch B, Hufnagel G, Kolsch S, Funck R, Richter A, Rupp H, Herzum M, Pankuweit S (2004) Treatment of inflammatory dilated cardiomyopathy and (peri)myocarditis with immunosuppression and i.v. immunoglobulins. Herz 29:624-636. doi: 10.1007/s00059-004-2628-7

96. Mann DL, McMurray JJ, Packer M, Swedberg K, Borer JS, Colucci WS, Djian J, Drexler H, Feldman A, Kober L, Krum H, Liu P, Nieminen M, Tavazzi L, van Veldhuisen DJ, Waldenstrom A, Warren M, Westheim A, Zannad F, Fleming T (2004) Targeted anticytokine therapy in patients with chronic heart failure: results of the Randomized Etanercept Worldwide Evaluation (RENEWAL). Circulation 109:1594-1602. doi: 10.1161/01.CIR.0000124490.27666.B2

97. Matsumoto K, Ogawa M, Suzuki J, Hirata Y, Nagai R, Isobe M (2011) Regulatory T lymphocytes attenuate myocardial infarction-induced ventricular remodeling in mice. Int Heart $\mathrm{J}$ 52:382-387 (pii:JST.JSTAGE/ihj/52.382)

98. McKinsey TA (2011) Targeting inflammation in heart failure with histone deacetylase inhibitors. Mol Med 17:434-441. doi: 10.2119/molmed.2011.00022

99. McMurray JJ, Adamopoulos S, Anker SD, Auricchio A, Bohm M, Dickstein K, Falk V, Filippatos G, Fonseca C, Gomez-Sanchez MA, Jaarsma T, Kober L, Lip GY, Maggioni AP, Parkhomenko A, Pieske BM, Popescu BA, Ronnevik PK, Rutten FH, Schwitter J, Seferovic P, Stepinska J, Trindade PT, Voors AA, Zannad F, Zeiher A (2012) ESC Guidelines for the diagnosis and treatment of acute and chronic heart failure 2012: The Task Force for the Diagnosis and Treatment of Acute and Chronic Heart Failure 2012 of the European Society of Cardiology. Developed in collaboration with the Heart Failure Association (HFA) of the ESC. Eur Heart J 33:1787-1847. doi:10.1093/ eurheartj/ehs 104

100. McMurray JJ, Adamopoulos S, Anker SD, Auricchio A, Bohm M, Dickstein K, Falk V, Filippatos G, Fonseca C, Gomez-Sanchez MA, Jaarsma T, Kober L, Lip GY, Maggioni AP, Parkhomenko A, Pieske BM, Popescu BA, Ronnevik PK, Rutten FH, Schwitter J, Seferovic P, Stepinska J, Trindade PT, Voors AA, Zannad F, Zeiher A, Bax JJ, Baumgartner H, Ceconi C, Dean V, Deaton C, Fagard R, Funck-Brentano C, Hasdai D, Hoes A, Kirchhof P, Knuuti J, Kolh P, McDonagh T, Moulin C, Reiner Z, Sechtem U, Sirnes PA, Tendera M, Torbicki A, Vahanian A, Windecker S, Bonet LA, Avraamides P, Ben Lamin HA, Brignole M, Coca A, Cowburn P, Dargie H, Elliott P, Flachskampf FA, Guida GF, Hardman S, Iung B, Merkely B, Mueller C, Nanas JN, Nielsen OW, Orn S, Parissis JT, Ponikowski P (2012) ESC guidelines for the diagnosis and treatment of acute and chronic heart failure 2012: the Task Force for the Diagnosis and Treatment of Acute and Chronic Heart Failure 2012 of the European Society of Cardiology. Developed in collaboration with the Heart Failure Association (HFA) of the ESC. Eur J Heart Fail 14:803-869. doi:10.1093/eurjhf/hfs105

101. McNamara DM, Holubkov R, Starling RC, Dec GW, Loh E, Torre-Amione G, Gass A, Janosko K, Tokarczyk T, Kessler P, Mann DL, Feldman AM (2001) Controlled trial of intravenous immune globulin in recent-onset dilated cardiomyopathy. Circulation 103:2254-2259

102. Meldrum DR (1998) Tumor necrosis factor in the heart. Am J Physiol 274:R577-R595 
103. Miles EA, Calder PC (2012) Influence of marine n-3 polyunsaturated fatty acids on immune function and a systematic review of their effects on clinical outcomes in rheumatoid arthritis. Br J Nutr 107(Suppl 2):S171-S184. doi:10.1017/S000 7114512001560

104. Moertl D, Hammer A, Steiner S, Hutuleac R, Vonbank K, Berger R (2011) Dose-dependent effects of omega-3-polyunsaturated fatty acids on systolic left ventricular function, endothelial function, and markers of inflammation in chronic heart failure of nonischemic origin: a double-blind, placebo-controlled, 3-arm study. Am Heart J 161(915):e911-e919. doi: 10.1016/j.ahj.2011.02.011

105. Munch G, Boivin-Jahns V, Holthoff HP, Adler K, Lappo M, Truol S, Degen H, Steiger N, Lohse MJ, Jahns R, Ungerer M (2012) Administration of the cyclic peptide COR-1 in humans (phase I study): ex vivo measurements of anti-beta1-adrenergic receptor antibody neutralization and of immune parameters. Eur J Heart Fail 14:1230-1239. doi:10.1093/eurjhf/hfs118

106. Nolan Y, Minogue A, Vereker E, Bolton AE, Campbell VA, Lynch MA (2002) Attenuation of LPS-induced changes in synaptic activity in rat hippocampus by Vasogen's Immune Modulation Therapy. Neuroimmunomodulation 10:40-46 (pi:nim10040)

107. Parissis JT, Venetsanou KF, Mentzikof DG, Ziras NG, Kefalas CG, Karas SM (1999) Tumor necrosis factor-alpha serum activity during treatment of acute decompensation of cachectic and non-cachectic patients with advanced congestive heart failure. Scand Cardiovasc J 33:344-350

108. Parrillo JE, Cunnion RE, Epstein SE, Parker MM, Suffredini AF, Brenner M, Schaer GL, Palmeri ST, Cannon RO 3rd, Alling D et al (1989) A prospective, randomized, controlled trial of prednisone for dilated cardiomyopathy. $N$ Eng $\mathrm{J}$ Med 321:1061-1068

109. Pei H, Qu Y, Lu X, Yu Q, Lian K, Liu P, Yan W, Liu J, Ma Y, Liu Y, Li C, Li W, Lau WB, Zhang H, Tao L (2013) Cardiacderived adiponectin induced by long-term insulin treatment ameliorates myocardial ischemia/reperfusion injury in type 1 diabetic mice via AMPK signaling. Basic Res Cardiol 108:322. doi:10.1007/s00395-012-0322-0

110. Platten M, Youssef S, Hur EM, Ho PP, Han MH, Lanz TV, Phillips LK, Goldstein MJ, Bhat R, Raine CS, Sobel RA, Steinman L (2009) Blocking angiotensin-converting enzyme induces potent regulatory $\mathrm{T}$ cells and modulates TH1- and TH17-mediated autoimmunity. Proc Natl Acad Sci USA 106:14948-14953. doi:10.1073/pnas.0903958106

111. Pokushalov E, Romanov A, Chernyavsky A, Larionov P, Terekhov I, Artyomenko S, Poveshenko O, Kliver E, Shirokova N, Karaskov A, Dib N (2010) Efficiency of intramyocardial injections of autologous bone marrow mononuclear cells in patients with ischemic heart failure: a randomized study. J Cardiovasc Transl Res 3:160-168. doi:10.1007/s12265-009-9123-8

112. Rauchhaus M, Doehner W, Francis DP, Davos C, Kemp M, Liebenthal C, Niebauer J, Hooper J, Volk HD, Coats AJ, Anker SD (2000) Plasma cytokine parameters and mortality in patients with chronic heart failure. Circulation 102:3060-3067

113. Richardson P, McKenna W, Bristow M, Maisch B, Mautner B, O'Connell J, Olsen E, Thiene G, Goodwin J, Gyarfas I, Martin I, Nordet P (1996) Report of the 1995 World Health Organization/ International Society and Federation of Cardiology Task Force on the Definition and Classification of cardiomyopathies. Circulation 93:841-842

114. Safinia N, Sagoo P, Lechler R, Lombardi G (2010) Adoptive regulatory $\mathrm{T}$ cell therapy: challenges in clinical transplantation. Curr Opin Organ Transpl 15:427-434. doi:10.1097/MOT.0b013 e32833bfadc
115. Sakaguchi S, Miyara M, Costantino CM, Hafler DA (2010) FOXP3+ regulatory $\mathrm{T}$ cells in the human immune system. Nat Rev Immunol 10:490-500. doi:10.1038/nri2785

116. Shaw SM, Shah MK, Williams SG, Fildes JE (2009) Immunological mechanisms of pentoxifylline in chronic heart failure. Eur J Heart Fail 11:113-118. doi:10.1093/eurjhf/hfn040

117. Shibata R, Ouchi N, Ito M, Kihara S, Shiojima I, Pimentel DR, Kumada M, Sato K, Schiekofer S, Ohashi K, Funahashi T, Colucci WS, Walsh K (2004) Adiponectin-mediated modulation of hypertrophic signals in the heart. Nat Med 10:1384-1389. doi:10.1038/nm1137

118. Singer G, Granger DN (2007) Inflammatory responses underlying the microvascular dysfunction associated with obesity and insulin resistance. Microcirculation 14:375-387. doi:10.1080/ 10739680701283158

119. Skudicky D, Bergemann A, Sliwa K, Candy G, Sareli P (2001) Beneficial effects of pentoxifylline in patients with idiopathic dilated cardiomyopathy treated with angiotensin-converting enzyme inhibitors and carvedilol: results of a randomized study. Circulation 103:1083-1088

120. Skudicky D, Sliwa K, Bergemann A, Candy G, Sareli P (2000) Reduction in Fas/APO-1 plasma concentrations correlates with improvement in left ventricular function in patients with idiopathic dilated cardiomyopathy treated with pentoxifylline. Heart $84: 438-439$

121. Sliwa K, Skudicky D, Candy G, Bergemann A, Hopley M, Sareli P (2002) The addition of pentoxifylline to conventional therapy improves outcome in patients with peripartum cardiomyopathy. Eur J Heart Fail 4:305-309 (pii:S1388984202000089)

122. Sliwa K, Skudicky D, Candy G, Wisenbaugh T, Sareli P (1998) Randomised investigation of effects of pentoxifylline on leftventricular performance in idiopathic dilated cardiomyopathy. Lancet 351:1091-1093. doi:10.1016/S0140-6736(97)09338-0

123. Sliwa K, Woodiwiss A, Candy G, Badenhorst D, Libhaber C, Norton G, Skudicky D, Sareli P (2002) Effects of pentoxifylline on cytokine profiles and left ventricular performance in patients with decompensated congestive heart failure secondary to idiopathic dilated cardiomyopathy. Am J Cardiol 90:1118-1122 (pi:S0002914902027790)

124. Sliwa K, Woodiwiss A, Kone VN, Candy G, Badenhorst D, Norton G, Zambakides C, Peters F, Essop R (2004) Therapy of ischemic cardiomyopathy with the immunomodulating agent pentoxifylline: results of a randomized study. Circulation 109:750-755. doi:10.1161/01.CIR.0000112568.48837.60

125. Staudt A, Bohm M, Knebel F, Grosse Y, Bischoff C, Hummel A, Dahm JB, Borges A, Jochmann N, Wernecke KD, Wallukat G, Baumann G, Felix SB (2002) Potential role of autoantibodies belonging to the immunoglobulin G-3 subclass in cardiac dysfunction among patients with dilated cardiomyopathy. Circulation 106:2448-2453

126. Staudt A, Hummel A, Ruppert J, Dorr M, Trimpert C, Birkenmeier K, Krieg T, Staudt Y, Felix SB (2006) Immunoadsorption in dilated cardiomyopathy: 6-month results from a randomized study. Am Heart J 152(712):e711-e716. doi: 10.1016/j.ahj.2006.06.027

127. Staudt A, Schaper F, Stangl V, Plagemann A, Bohm M, Merkel K, Wallukat G, Wernecke KD, Stangl K, Baumann G, Felix SB (2001) Immunohistological changes in dilated cardiomyopathy induced by immunoadsorption therapy and subsequent immunoglobulin substitution. Circulation 103:2681-2686

128. Staudt A, Staudt Y, Dorr M, Bohm M, Knebel F, Hummel A, Wunderle L, Tiburcy M, Wernecke KD, Baumann G, Felix SB (2004) Potential role of humoral immunity in cardiac dysfunction of patients suffering from dilated cardiomyopathy. J Am Coll Cardiol 44:829-836. doi:10.1016/j.jacc.2004.04.055 
129. Stork S, Boivin V, Horf R, Hein L, Lohse MJ, Angermann CE, Jahns R (2006) Stimulating autoantibodies directed against the cardiac beta1-adrenergic receptor predict increased mortality in idiopathic cardiomyopathy. Am Heart J 152:697-704. doi: 10.1016/j.ahj.2006.05.004

130. Takada H, Kishimoto C, Hiraoka Y (1995) Therapy with immunoglobulin suppresses myocarditis in a murine coxsackievirus B3 model. Antiviral and anti-inflammatory effects. Circulation 92:1604-1611

131. Tang TT, Ding YJ, Liao YH, Yu X, Xiao H, Xie JJ, Yuan J, Zhou ZH, Liao MY, Yao R, Cheng Y, Cheng X (2010) Defective circulating CD4CD25+Foxp3+CD127(low) regulatory T-cells in patients with chronic heart failure. Cell Physiol Biochem 25:451-458. doi:10.1159/000303050

132. Tang TT, Yuan J, Zhu ZF, Zhang WC, Xiao H, Xia N, Yan XX, Nie SF, Liu J, Zhou SF, Li JJ, Yao R, Liao MY, Tu X, Liao YH, Cheng $X$ (2012) Regulatory $T$ cells ameliorate cardiac remodeling after myocardial infarction. Basic Res Cardiol 107:232. doi:10.1007/s00395-011-0232-6

133. Tavazzi L, Maggioni AP, Marchioli R, Barlera S, Franzosi MG, Latini R, Lucci D, Nicolosi GL, Porcu M, Tognoni G (2008) Effect of $n-3$ polyunsaturated fatty acids in patients with chronic heart failure (the GISSI-HF trial): a randomised, double-blind, placebo-controlled trial. Lancet 372:1223-1230. doi:10.1016/ S0140-6736(08)61239-8

134. Tavazzi L, Maggioni AP, Marchioli R, Barlera S, Franzosi MG, Latini R, Lucci D, Nicolosi GL, Porcu M, Tognoni G (2008) Effect of rosuvastatin in patients with chronic heart failure (the GISSI-HF trial): a randomised, double-blind, placebo-controlled trial. Lancet 372:1231-1239. doi:10.1016/S0140-6736(08)61240-4

135. Taylor AL, Ziesche S, Yancy C, Carson P, D'Agostino R Jr, Ferdinand K, Taylor M, Adams K, Sabolinski M, Worcel M, Cohn JN (2004) Combination of isosorbide dinitrate and hydralazine in blacks with heart failure. $\mathrm{N}$ Engl $\mathrm{J}$ Med 351:2049-2057. doi:10.1056/NEJMoa042934

136. Taylor AL, Ziesche S, Yancy CW, Carson P, Ferdinand K, Taylor M, Adams K, Olukotun AY, Ofili E, Tam SW, Sabolinski ML, Worcel M, Cohn JN (2007) Early and sustained benefit on event-free survival and heart failure hospitalization from fixeddose combination of isosorbide dinitrate/hydralazine: consistency across subgroups in the African-American Heart Failure Trial. Circulation 115:1747-1753. doi:10.1161/CIRCULA TIONAHA.106.644013

137. Theiss HD, David R, Engelmann MG, Barth A, Schotten K, Naebauer M, Reichart B, Steinbeck G, Franz WM (2007) Circulation of $\mathrm{CD} 34+$ progenitor cell populations in patients with idiopathic dilated and ischaemic cardiomyopathy (DCM and ICM). Eur Heart J 28:1258-1264. doi:10.1093/eurheartj/ehm011

138. Thielmann M, Dorge H, Martin C, Belosjorow S, Schwanke U, van De Sand A, Konietzka I, Buchert A, Kruger A, Schulz R, Heusch G (2002) Myocardial dysfunction with coronary microembolization: signal transduction through a sequence of nitric oxide, tumor necrosis factor-alpha, and sphingosine. Circ Res 90:807-813

139. Thum T, Bauersachs J, Poole-Wilson PA, Volk HD, Anker SD (2005) The dying stem cell hypothesis: immune modulation as a novel mechanism for progenitor cell therapy in cardiac muscle. J Am Coll Cardiol 46:1799-1802. doi:10.1016/j.jacc.2005. 07.053

140. Tinkel J, Hassanain H, Khouri SJ (2012) Cardiovascular antioxidant therapy: a review of supplements, pharmacotherapies, and mechanisms. Cardiol Rev 20:77-83. doi:10.1097/CRD. Ob013e31823dbbad

141. Torre-Amione G, Anker SD, Bourge RC, Colucci WS, Greenberg BH, Hildebrandt P, Keren A, Motro M, Moye LA, Otterstad JE, Pratt CM, Ponikowski P, Rouleau JL, Sestier F,
Winkelmann BR, Young JB (2008) Results of a non-specific immunomodulation therapy in chronic heart failure (ACCLAIM trial): a placebo-controlled randomised trial. Lancet 371:228 236. doi:10.1016/S0140-6736(08)60134-8

142. Torre-Amione G, Kapadia S, Lee J, Bies RD, Lebovitz R, Mann DL (1995) Expression and functional significance of tumor necrosis factor receptors in human myocardium. Circulation 92:1487-1493

143. Torre-Amione G, Kapadia S, Lee J, Durand JB, Bies RD, Young JB, Mann DL (1996) Tumor necrosis factor-alpha and tumor necrosis factor receptors in the failing human heart. Circulation 93:704-711

144. Torre-Amione G, Sestier F, Radovancevic B, Young J (2004) Effects of a novel immune modulation therapy in patients with advanced chronic heart failure: results of a randomized, controlled, phase II trial. J Am Coll Cardiol 44:1181-1186. doi: 10.1016/j.jacc.2004.06.047

145. van den Akker F, Deddens JC, Doevendans PA, Sluijter JP (2012) Cardiac stem cell therapy to modulate inflammation upon myocardial infarction. Biochim Biophys Acta. doi:10.1016/ j.bbagen.2012.08.026

146. Vanderheyden M, Paulus WJ, Voss M, Knuefermann P, Sivasubramanian N, Mann D, Baumgarten G (2005) Myocardial cytokine gene expression is higher in aortic stenosis than in idiopathic dilated cardiomyopathy. Heart 91:926-931. doi: 10.1136/hrt.2004.035733

147. Voll RE, Herrmann M, Roth EA, Stach C, Kalden JR, Girkontaite I (1997) Immunosuppressive effects of apoptotic cells. Nature 390:350-351. doi:10.1038/37022

148. Vrtovec B, Poglajen G, Lezaic L, Sever M, Domanovic D, Cernelc P, Socan A, Schrepfer S, Torre-Amione G, Haddad F, Wu JC (2012) Effects of Intracoronary Cd34 + Stem Cell Transplantation in Non-Ischemic Dilated Cardiomyopathy Patients: 5-Year Follow Up. Circ Res 112:165-173. doi: 10.1161/CIRCRESAHA.112.276519

149. Wang L, de Zoeten EF, Greene MI, Hancock WW (2009) Immunomodulatory effects of deacetylase inhibitors: therapeutic targeting of FOXP3 + regulatory T cells. Nat Rev Drug Discov 8:969-981. doi:10.1038/nrd3031

150. Wojnicz R, Nowalany-Kozielska E, Wojciechowska C, Glanowska G, Wilczewski P, Niklewski T, Zembala M, Polonski L, Rozek MM, Wodniecki J (2001) Randomized, placebo-controlled study for immunosuppressive treatment of inflammatory dilated cardiomyopathy: two-year follow-up results. Circulation 104:39-45

151. Wynn TA, Barron L (2010) Macrophages: master regulators of inflammation and fibrosis. Semin Liver Dis 30:245-257. doi: 10.1055/s-0030-1255354

152. Yamagishi K, Iso H, Date C, Fukui M, Wakai K, Kikuchi S, Inaba Y, Tanabe N, Tamakoshi A (2008) Fish, omega-3 polyunsaturated fatty acids, and mortality from cardiovascular diseases in a nationwide community-based cohort of Japanese men and women the JACC (Japan Collaborative Cohort Study for Evaluation of Cancer Risk) Study. J Am Coll Cardiol 52:988-996. doi:10.1016/j.jacc.2008.06.018

153. Yamaguchi O, Higuchi Y, Hirotani S, Kashiwase K, Nakayama H, Hikoso S, Takeda T, Watanabe T, Asahi M, Taniike M, Matsumura Y, Tsujimoto I, Hongo K, Kusakari Y, Kurihara S, Nishida K, Ichijo H, Hori M, Otsu K (2003) Targeted deletion of apoptosis signal-regulating kinase 1 attenuates left ventricular remodeling. Proc Natl Acad Sci USA 100:15883-15888. doi: 10.1073/pnas.2136717100

154. Yokoyama T, Nakano M, Bednarczyk JL, McIntyre BW, Entman M, Mann DL (1997) Tumor necrosis factor-alpha provokes a hypertrophic growth response in adult cardiac myocytes. Circulation 95:1247-1252 
155. Yokoyama T, Vaca L, Rossen RD, Durante W, Hazarika P, Mann DL (1993) Cellular basis for the negative inotropic effects of tumor necrosis factor-alpha in the adult mammalian heart. J Clin Invest 92:2303-2312. doi:10.1172/JCI116834

156. Yu Q, Horak K, Larson DF (2006) Role of T lymphocytes in hypertension-induced cardiac extracellular matrix remodeling. Hypertension 48:98-104. doi:10.1161/01.HYP.0000227247. 27111.b2

157. Yu Q, Vazquez R, Khojeini EV, Patel C, Venkataramani R, Larson DF (2009) IL-18 induction of osteopontin mediates cardiac fibrosis and diastolic dysfunction in mice. Am J Physiol Heart Circ Physiol 297:H76-H85. doi:10.1152/ajpheart.01 285.2008
158. Zhang H, Potter BJ, Cao JM, Zhang C (2011) Interferon-gamma induced adipose tissue inflammation is linked to endothelial dysfunction in type 2 diabetic mice. Basic Res Cardiol 106:1135-1145. doi:10.1007/s00395-011-0212-x

159. Zhang M, Alicot EM, Chiu I, Li J, Verna N, Vorup-Jensen T, Kessler B, Shimaoka M, Chan R, Friend D, Mahmood U, Weissleder R, Moore FD, Carroll MC (2006) Identification of the target self-antigens in reperfusion injury. J Exp Med 203:141-152. doi:10.1084/jem.20050390

160. Zhu J, Liu M, Kennedy RH, Liu SJ (2006) TNF-alpha-induced impairment of mitochondrial integrity and apoptosis mediated by caspase- 8 in adult ventricular myocytes. Cytokine 34:96105. doi:10.1016/j.cyto.2006.04.010 